\title{
Człowiek sprawiedliwy a człowiek bezbożny w świetle Ps 37
}

\author{
The Righteous and the Wicked in the Light of Psalm 37
}

\author{
MYKHAYLYNA KLUSKOVÁ \\ Wydział Pedagogiczny Katolickiego Uniwersytetu w Rużomberku (Słowacja) \\ e-mail: mykhaylyna.kluskova@gmail.com \\ ORCID: 0000-0003-0896-6945
}

\begin{abstract}
Psalm 37 is one of the most typical wisdom texts in the Book of Psalms. In comparison to other psalms it contains a high number of information on the righteous and the wicked person. The paper aims to present and analyse in detail all contexts in which mentions of the righteous and the wicked appear in order to answer the question what function these information have. The paper is divided into three main parts. In the first one is given a short introduction into psalm's genre, its structure and main topic. In the second and third part of the paper the information about the righteous and the wicked are analysed in detail and the main contexts of their using are defined. The analysis presented in these two parts reflects all mentions of the righteous and the wicked in Ps 37, such containing

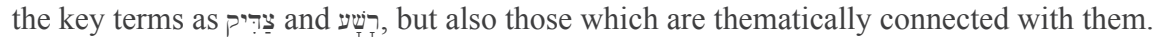
The righteous as supported by God are mainly viewed as existential winners in contrast to the wicked presented as life losers. The final part of the article explains in short the role of the information on the righteous and the wicked in Ps 37 taking into account the actual situation of the psalm's addressee.
\end{abstract}

KEYwords: Book of Psalms, Ps 37, alphabetical psalm, wisdom psalm, the righteous, the wicked

SŁowA KLuCzowe: Psałterz, Ps 37, psalm alfabetyczny, psalm mądrościowy, sprawiedliwy, bezbożny

$\mathrm{P}$

salm 37 jest jednym z tekstów biblijnych, w których wielokrotnie pojawiają

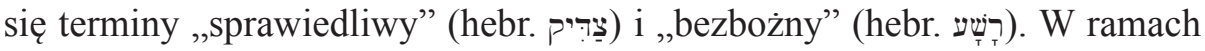
Psałterza jest to utwór, w którym te hebrajskie określenia występują najczęściej:

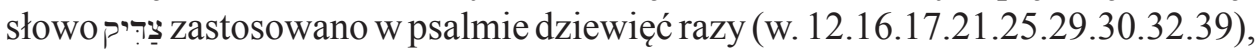
רצָשע - trzynaście razy (w. 10.12.14.16.17.20.21.28.32.34.35.38.40)1․ Okoliczność ta budzi zainteresowanie oraz skłania do podjęcia refleksji nad przyczyną tego zjawiska. Stąd też jest rzeczą zrozumiałą, że w badaniach nad Ps 37 pojawiają się takie, które literackie motywy „sprawiedliwego” oraz „bezbożnego” czynią

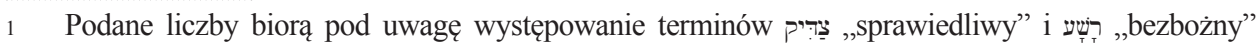
w liczbie pojedynczej oraz mnogiej. 
szczególnym przedmiotem swojej uwagi². Wpisując się w ten nurt, niniejszy artykuł proponuje analizę Ps 37 pod kątem występowania w nim motywów „sprawiedliwego" i ,bezbożnego”. Celem przedkładanego przyczynku jest odpowiedź na pytanie, co Ps 37 mówi o sprawiedliwym i bezbożnym, a także odkrycie tego, jaką funkcję w ramach całego psalmu przypisuje się informacjom o sprawiedliwym i bezbożnym. Po krótkiej charakterystyce utworu przedstawię analizę motywu człowieka sprawiedliwego i bezbożnego w Ps 37. W końcowej części artykułu skupię się nad odczytaniem funkcji informacji o sprawiedliwym i bezbożnym w analizowanym tekście.

\section{Ogólna charakterystyka Ps 37}

Psalm 37 nosi wyraźne znamiona utworu mądrościowego ${ }^{3}$. Chociaż pojawia się on w zbiorze tekstów modlitewnych, nie może być uznany za modlitwę, ponieważ nie dysponuje żadnym wezwaniem skierowanym do Boga oraz nigdzie nie zwraca się do Boga wprost. Adresatem tego psalmu jest człowiek, który płonie względem bezbożnego gniewem i zazdrością bądź jest bardzo bliski takich zachowań. Psalmista stara się pouczyć adresata, formułując swoje myśli w stylu mądrościowym oraz odwołując się do typowo mądrościowych gatunków literackich. Swojego odbiorcę autor napomina (w. 1.7.8.27a), dzieli się z nim swoim doświadczeniem (w. 25.35-36), wzywa do pełnienia określonych czynności oraz zachęca do konkretnych postaw, dołączając do pouczenia różnego rodzaju obietnice (w. 3-7a $\alpha \cdot 27.37-38^{4}$ ). Hagiograf często stosuje antytezy (np. w. 9.10-

2 Zob. np. M. Jinkins, „The Virtues of the Righteous in Psalm 37”, Psalms and Practice. Worship, Virtue, and Authority (red. St. B. Reid) (Collegeville: The Liturgical Press 2001) 164-201; M. Saur, „Frevler und Gerechte. Überlegungen zum theologischen Ort von Psalm 37”, Nächstenliebe und Gottesfurcht. Beiträge aus alttestamentlicher, semitistischer und altorientalischer Wissenschaft für Hans-Peter Mathys zum 65. Geburtstag (red. H. Jenni - M. Saur) (Alter Orient und Altes Testament 439; Münster: Ugarit Verlag 2016) 375-392.

3 W literaturze naukowej pojawiają się również głosy kwalifikujące Ps 37 jako dzieło o charakterze apokaliptycznym bądź eschatologicznym. Zob. np. N. Lohfink, „Die Besänftigung des Messias: Gedanken zu Psalm 37”, „Den Armen eine frohe Botschaft”: Festschrift für Bischof Franz Kamphaus zum 65. Geburtstag (red. J. Hainz i in.) (Frankfurt am Main: Josef Knecht 1997) 87. Pierwszym świadectwem literackim rozumienia badanego utworu w kategoriach eschatologicznych jest qumrański komentarz do Ps 37 -4QpPs37 (4Q171). Więcej na temat eschatologicznej interpretacji Ps 37 we wspomnianym peszerze czytaj w artykule F. Manns, ,Blessed are the Meek for they Shall Inherit the Earth", LA 50 (2000) 43-46. We współczesnej biblistyce Ps 37 jest także uznawany za utwór o cechach eschatologicznej mądrości. Zob. M. Witte, „Psalm 37 im Spannungsfeld von Weisheit und Eschatologie", M. Witte, Von Ewigkeit zu Ewigkeit. Weisheit und Geschichte in den Psalmen (Biblisch-Theologische Studien 146; Neukirchen-Vluyn: Neukirchener Verlag 2014) 44-59.

4 Do obietnic możemy zaliczyć również informacje o przyszłym losie ludzi niegodziwych oraz sprawiedliwych, które pojawiają się po upomnieniach skierowanych do adresata psalmu (zob. w. 2.911.27). 
11.17.19-20.21.22) oraz wykorzystuje siłę perswazji ukrytej w przysłowiach (np. w. 16). Oprócz tego mówi wprost o mądrości, która charakteryzuje sprawiedliwego (w. 30-31). Bibliści zwracają również uwagę na bliskość wypowiedzi zawartych w Ps 37 do sformułowań występujących w Księdze Przysłów, co jest najbardziej widoczne przy porównaniu tekstu Ps 37 z fragmentami Prz 10,27-32 oraz 24,1-22 . W ramach Psałterza Ps 37 wykazuje podobieństwo tematyczne zwłaszcza z Ps $1^{6}$ i Ps $73^{7}$.

Cechą charakterystyczną Ps 37 jest jego układ alfabetyczny. Z wykorzystaniem podobnej struktury mamy do czynienia nie tylko w Psałterzu (np. Ps 9-10; 34; 119), ale także w literaturze sapiencjalnej (np. Prz 31). Celem zastosowania takiej budowy utworu jest prawdopodobnie chęć podkreślenia, że temat podjęty przez autora był opracowany w sposób kompletny i wyczerpujący ${ }^{8}$. Zdaniem Johna Goldingaya alfabetyczna struktura Ps 37 odpowiada wyrażonemu w nim przeświadczeniu o istnieniu porządku w świecie9.

W opinii niektórych egzegetów układ alfabetyczny Ps 37 jest jedyną strukturą zauważalną $\mathrm{w}$ utworze ${ }^{10}$. W analizowanym tekście nie dostrzegają oni rozwoju myśli, raczej cykliczne powracanie do tego samego tematu ${ }^{11}$. Nie brak jednak autorów, którzy, głównie biorąc pod uwagę treść utworu, dopatrują się pewnej logiki w takim, a nie innym układzie materiału ${ }^{12}$. Za najbardziej przekonywującą

5 Zob. A.F. Kirkpatrick, The Book of Psalms (The Cambridge Bible for Schools and Colleges; Cambridge: University Press 1951) 188; A. Hurvitz, „Wisdom Vocabulary in the Hebrew Psalter”, VT 38/1 (1988) 49; L. Alonso Schökel - C. Carniti, I Salmi (Commenti biblici; Roma: Borla 1992) 630; A. Hurvitz, ,tsdyq = ,wise“ in biblical Hebrew and the wisdom connections of Ps 37", "Goldene Äpfel in silbernen Schalen» (red. K.-D. Schunck - M. Augustin) (Beitrage zur Erforschung des Alten Testaments und des antiken Judentums 20; Frankfurt am Main: Peter Lang 1992) 109-112; F.-L. Hossfeld - E. Zenger, Die Psalmen I. Psalm 1-50 (Die Neue Echter Bibel. Kommentar zum Alten Testament mit der Einheitsübersetzung; Würzburg: Echter Verlag 1993) 230; N. Lohfink, „Die Besänftigung des Messias: Gedanken zu Psalm 37”, 80-81; R.E. Murphy, The Tree of Life. An Exploration of Biblical Wisdom Literature (Grand Rapids: Eerdmans 2002) 221; J. Goldingay, Psalms 1-41 (Baker Commentary on the Old Testament Wisdom and Psalms; Grand Rapids: Baker Academic 2006) 517; G.W. Grogan, Psalms (The Two Horizons Old Testament Commentary; Grand Rapids: Eerdmans 2008) 91.

6 Zob. Goldingay, Psalms 1-41, 517.

7 Zob. M. Oeming, Das Buch der Psalmen. Psalm 1-41 (Neuer Stuttgarter Kommentar - Altes Testament 13/1; Stuttgart: Katholisches Bibelwerk 2000) 207.

8 Zob. P.C. Craigie, Psalms 1-50 (Word Biblical Commentary; Waco: Word Books 1983) 129; Ch.J. Fantuzzo, „Acrostic”, Dictionary of the Old Testament Wisdom, Poetry \& Writings. A Compendium of Contemporary Biblical Scholarship (red. T. Longman III - P. Enns) (Nottingham: IVP Academic 2008) 4.

9 Zob. Goldingay, Psalms 1-41, 517.

$10 \quad$ Zob. Craigie, Psalms 1-50, 296.

11 Zob. Goldingay, Psalms 1-41, 517.

12 W komentarzach niejednokrotnie napotykamy na podział utworu na cztery części, w których zdaniem egzegetów przechodzi się od nawoływań do ufności Bogu (w. 1-11), poprzez ukazanie upadku bezbożnego (w. 12-20) i nagrody dla sprawiedliwego (w. 21-31), do ponownego przedstawienia kontrastu między losem sprawiedliwego i bezbożnego (w. 32-40). Zob. Kirkpatrick, The Book of Psalms, 
można uznać propozycję podziału Ps 37 przedstawioną przez E. Zengera, który, bazując na kryteriach syntaktycznych i semantycznych, dzieli tekst na trzy części (I: w. 1-11; II: w. 12-26; III: w. 27-40) $)^{13}$. Część pierwsza jest zdominowana przez imperatywy o charakterze ostrzeżeń i upomnień, przy czym zachowania, do których autor zachęca swojego adresata, są na końcu motywowane obietnicą ziemi. Imperatywy występują również w trzeciej części utworu, z tą jednak różnicą, że wyrażają wyłącznie upomnienia - nawołują do pewnych postaw (imperatywy są formułowane w sposób pozytywny). Druga część Ps 37 skupia swoją uwagę na osobach „bezbożnego” i „sprawiedliwego”. W dużej mierze tę część tworzą zdania nominalne. Na jej końcu pojawia się obietnica ziemi, która ma pomóc adresatowi w wyprowadzeniu wniosków z przedstawionego pouczenia. Z podobną koncentracją uwagi na antytetycznych figurach „bezbożnego” i ,sprawiedliwego" spotkamy się również w trzeciej części utworu, przy czym od samego początku mamy do czynienia z wyraźnym odniesieniem sprawiedliwego do Boga („Jego święci/,„Jego pobożni”, w. 28) ${ }^{14}$.

Na bazie wstępnych wierszy tekstu (w. 1-8) staje się zrozumiałe, że podstawową kwestią do wyjaśnienia jest to, jaki ma być stosunek adresata psalmu do ludzi, którzy popełniają zło. Pamiętając o tym kluczowym problemie analizowanego psalmu, przejdźmy do bardziej szczegółowego omówienia informacji o człowieku sprawiedliwym i bezbożnym, w które dany utwór obfituje. Podstawą dla analizy będzie masorecki tekst hebrajski. Biorąc pod uwagę fakt, że w psalmie pojawia się jako pierwszy termin רִָּ (w. 10), zaczniemy analizę od uwzględnienia tych miejsc tekstu, w których jest mowa o bezbożnym.

\section{Analiza motywu człowieka bezbożnego w Ps 37}

W tej części artykułu najpierw przedstawimy zastosowane w Ps 37 określenia odnoszące się do człowieka bezbożnego. Uwzględnimy przy tym strukturę analizowanego tekstu oraz spróbujemy odkryć „logikę” wykorzystania konkretnych

188; A.A. Anderson, The Book of Psalms. Volume I. Psalms 1-72 (New Century Bible Commentary; Grand Rapids: Eerdmans 1981) 292; J.H. Eaton, The Psalms. A Historical and Spiritual Commentary with an Introduction and New Translation (London - New York: Continuum 2005) 164. Z podziałem Ps 37 na pięć części spotkamy się u B.T. Tannera. Zob. N. Declaisse-Walford - R.A. Jacobson B.T. Tanner, The Book of Psalms (The New International Commentary on the Old Testament; Grand Rapids: Eerdmanns 2014) 348. Wśród propozycji struktur badanego utworu pojawiają się również takie, które dopatrują się w całym Ps 37 bądź w niektórych jego częściach układu koncentrycznego. Zob. S. Terrien, The Psalms. Strophic Structure and Theological Commentary. Volume II. Psalms 73-150 (The Eerdmans Critical Commentary; Grand Rapids: Eerdmans 2003) 321; R. Benun, „Evil and the Disruption of Order: A Structural Analysis of the Acrostics in the First Book of Psalms", JHS 6 (2006) 16-17, http://www.jhsonline.org/Articles/article_55.pdf [dostęp: 24.09.2018].

13 Zob. Hossfeld - Zenger, Die Psalmen I. Psalm 1-50, 230-231.

14 Zob. Hossfeld - Zenger, Die Psalmen I. Psalm 1-50, 230-231. 
terminów i pozostałych określeń w poszczególnych częściach utworu. Następnie dokonamy analizy kontekstów występowania określeń odnoszących się do człowieka bezbożnego w zajmującym nas psalmie.

\subsection{Określenia odnoszące się do człowieka bezbożnego w Ps 37}

Po raz pierwszy Ps 37 mówi o bezbożnym jako רָָּ w w. 10. Od tego miejsca aż do końca tekstu רָּ (w tym także jego potomstwo, zob. w. 28.38) będzie głów-

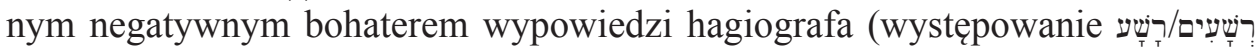
w w. 10.12.14.16.17.20.21.28.32.34.35.38.40). Inne określenia, jak np. „wrogowie Jhwh”, „przeklęci”, „grzesznicy” pojawią się w tekście jedynie raz, przy czym wystąpią one bądź w paralelizmie do twierdzeń dotyczących człowieka bezbożnego/jego potomstwa (w. 20.38) ${ }^{15}$, bądź w konstrukcji podobnej do tej, w której jest mowa o człowieku bezbożnym/jego potomstwie (w. 22) ${ }^{16}$. W po-

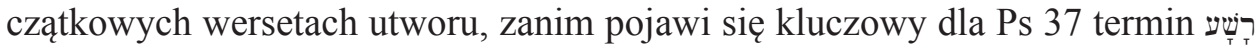
„bezbożny”, autor mówi o „złoczyńcach” (w. 1a.9), „tych, którzy czynią nieprawość” (w. 1b), „odnoszą sukces” (w. 7a) oraz „snują intrygi” (w. 7b). Wspomniane określenia występują w kontekstach bardzo podobnych do tych, w których w późniejszych wersetach będzie mowa o bezbożnych (por. obietnica definitywnego końca ludzi niegodziwych w w. 1-2.7-9 i w. 10.20.28.34.35-36).

W świetle powyższego człowiek bezbożny - רִֹ - jawi się czytelnikowi jako główna kategoria negatywna Ps 37. Interesujące jest to, że z największą koncentracją terminu „bezbożny” mamy do czynienia w drugiej oraz trzeciej części utworu, w których dochodzi do konfrontowania człowieka bezbożnego z człowiekiem sprawiedliwym (w. 12-26: 7 razy; 27-40: 5 razy), podczas gdy w części pierwszej, gdzie takiego zestawienia brak, termin רָָּ pojawia się tylko w jednym wersecie (w. 10). Może zastanawiać fakt, że autor nie posługuje się danym słowem w początkowych wersetach tego psalmu. Uwzględnienie znaczenia określeń synonimicznych terminu רָָּ w w. 1-9 wyjaśnia taki stan rzeczy. W w. 1-11, które są kluczowe dla odkrycia problemu adresata Ps 37, bezbożny zyskuje jedno-

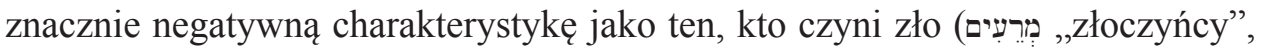

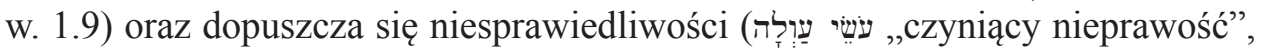

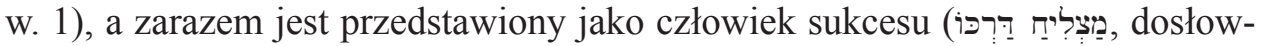
nie ,powodujący/zapewniający prosperowanie swojej drodze”, w. 7). Istotne jest zwłaszcza określenie niegodziwych jako עשׁי עַוְלדה, dzięki czemu zwraca się uwagę

15 Ps 37,20: „Bezbożni natomiast poginą; wrogowie Pana jak ozdoba pastwisk skończą się, w dymie skończą się”; Ps 37,38: „Ale grzesznicy [wszyscy] razem będą wyniszczeni, potomstwo [dosłownie $<<$ przyszłość>> $>$ bezbożnych będzie wycięte".

16 Ps 37,22: ,ponieważ błogosławieni przez Niego [Boga] posiądą ziemię, przeklęci przez Niego [Boga] będą wycięci", por. w. 28-29. 
na charakterystyczne dla ich postawy odstąpienie od porządku ustanowionego przez Boga, które ma miejsce w sferze społecznej oraz włącza w siebie relacje międzyludzkie ${ }^{17}$. W odróżnieniu od עשיטי עַוְְל adresat Ps 37 ma czynić dobro (imperatyw עִשֶה-טוֹב ,czyń dobro”, w. 3) oraz, ufając w Jhwh, ma pozwolić Jemu

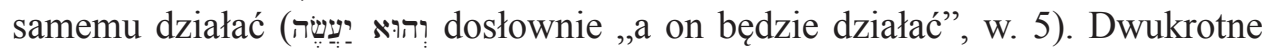
zastosowanie słowa מְרִֵים (imiesłów od רעע hifil) można z kolei potraktować jako uzasadnione w kontekście nawoływań do zaniechania przez adresata Ps 37 gniewu, który może doprowadzić do tego, iż on sam, skądinąd dążący do sprawiedliwości (w. 6), stanie się złym (הָרֵ - bezokolicznik od hifil), co w konsekwencji może wieść ku zagładzie - przewidzianej dla wszystkich מְרִעִ (w. 8-9). Termin

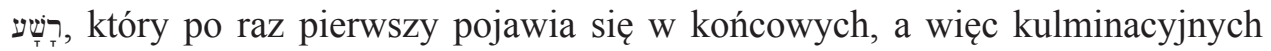
wersetach pierwszej części Ps 37 (w. 10), jakby kumuluje w sobie wszystkie podane wcześniej istotne charakterystyki człowieka bezbożnego, który w drugiej i trzeciej części utworu będzie zestawiany z człowiekiem sprawiedliwym.

Bezbożny z w. 12-26 oraz 27-40 to nie tylko postać przeciwstawna w stosunku do sprawiedliwego. Dzięki zastosowaniu określeń „wrogowie Jhwh” (w. 19), „przeklęci” (w. 22), ,grzesznicy” (w. 38) autor konfrontuje bezbożnych z Bogiem oraz ocenia ich w kategoriach religijnych. Występowanie wspomnianych terminów bądź związków słownych w odniesieniu do ludzi bezbożnych jest uzasadnione i dobrze koresponduje z kontekstem. „Wrogowie Jhwh” to ci, którzy w świetle wcześniejszych wersetów knują zło oraz zachowują się jako nieprzyjaciele ludzi należących do kategorii sprawiedliwych (w. 12.14). O „nienagannych” troszczy się Pan (w. 18), ale bezbożni jako „wrogowie Jhwh” zginą (w. 20), jakby doświadczając na sobie „sprawiedliwości” za wrogość żywioną przeciwko tym, których Bóg podtrzymuje. Bezbożni jako „przeklęci przez Niego” [Jhwh] są doskonałą figurą przeciwstawną w stosunku do sprawiedliwych, którzy są „błogosławieni przez Niego" [Jhwh] (w. 22). Bezbożni zaś określeni mianem „grzeszników” (hebr.

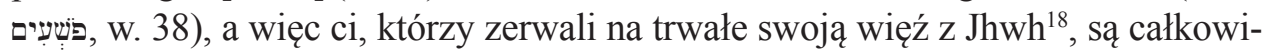
tym przeciwieństwem tych, którzy jako „niewinni”/"bez zarzutu”, ,prości” (w. 37)

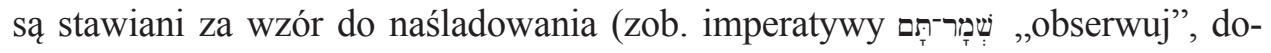

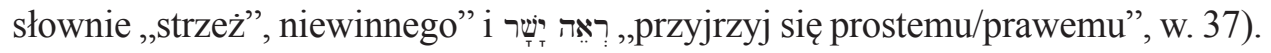

\subsection{Analiza kontekstów występowania określeń odnoszących się do człowieka bezbożnego w Ps 37}

Na podstawie analizy tych miejsc Ps 37, w których pojawia się termin רִֹ bądź

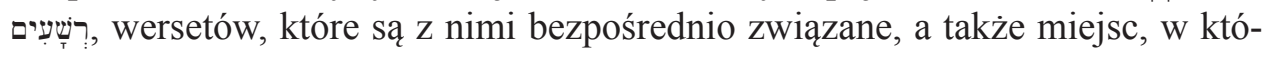

17 Zob. J. Schreiner, ,עיָ eāwel injustice”, TDOT, X 524-525, 527.

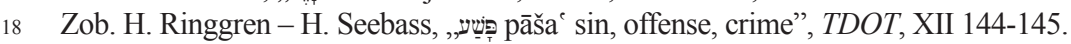


rych występują określenia paralelne do terminu רָָּ odkryto trzy główne konteksty występowania wzmianek o bezbożnych. Po pierwsze w tekście jest mowa o ich zniszczeniu bądź zniknięciu. Po drugie autor Ps 37 mówi o sytuacji zagrożenia, którą bezbożny wytwarza dla człowieka sprawiedliwego. Trzecim kontekstem, w którym hagiograf odnosi się do bezbożnych, są fragmenty opisujące ich sytuację ekonomiczną.

Pierwsza grupa wzmianek o bezbożnych jest najliczniejsza. Psalmista w kilku miejscach przekonuje swojego adresata, że losem bezbożnego jest zniszczenie bądź zniknięcie (w. 2.9. 10.20.22.28.34.35-36.38).

Przy opisie zniszczenia bezbożnych autor najczęściej posługuje się czasownikami utworzonymi od hebrajskiego rdzenia כרת (por. w. 9.22.28.34.38), który jako podstawową zawiera w sobie ideę cięcia, ścinania, wycinania. W tym sensie niejednokrotnie odnosi się on w tekstach biblijnych do czynności ścinania drzew (np. $1 \mathrm{Krl}$ 5,20; $2 \mathrm{Krn}$ 2,7.9.15; Jr 6,6; 10,3). Znaczenie tej osnowy w koniugacji nifal, w której występują wszystkie zastosowane w Ps 37 pochodne osnowy כרת, jest naznaczone intensywnością oraz wskazuje na rzeczywistość wygubienia. Zniszczenie, do którego odnosi się rdzeń כרת, niekoniecznie wiąże się w tekstach biblijnych z fizyczną eksterminacją. Równie dobrze może opisywać sytuację wyłączenia ze wspólnoty kultu bądź przymierza kogoś, na kim ciąży pewnego rodzaju wykroczenie ${ }^{19}$. Jest rzeczą interesującą, że w Księdze Przysłów mówi się o wygubieniu, w sensie dosłownym o „wycięciu” bezbożnego z ziemi przy równoczesnej wzmiance o przyszłym zamieszkaniu w niej człowieka sprawiedliwego (Prz 2,21-2220; por. 10,30). W Starym Testamencie przedstawia się również upadek dużego imperium jako „wycięcie” dużego i okazałego drzewa (np. Ez 31,12). Kontekst zastosowania pochodnych rdzenia כרת w Starym Testamencie skłania czytelnika Ps 37 do zwrócenia szczególnej uwagi na te miejsca tekstu, w których jest mowa o „wycięciu” bezbożnych w paralelizmie do wzmianek o dziedziczeniu ziemi przez sprawiedliwych (zob. 3.2), a także prowadzi do uznania za znaczące dla zrozumienia przesłania Ps 37 porównania bezbożnego do bujnego drzewa, które jest zawarte w wersecie 35. W Ps 37 nigdzie nie ma mowy o tym, kto dokona zniszczenia. W tekstach Psałterza niejednokrotnie spotkamy się jednak z przeświadczeniem, że Jhwh jest w stanie spowodować zniszczenie bezbożnych, będących zagrożeniem dla sprawiedliwych (por. np. 34,17; 109,15 , por. również 12,4). John Goldingay uważa, iż od pierwszego pojawienia się czasownika utworzonego od rdzenia wָָָ w Ps 37 (w. 9) aż do w. $34^{21}$ możemy, na bazie paralelizmu wypowiedzi o losie bezbożnych do twierdzeń o przyszło-

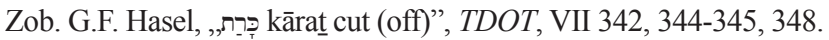

20 „Ziemia”, z którą wiążą się przyszłe losy bezbożnego i sprawiedliwego w Prz 2,21-22, jest tak samo bliżej nieokreślona jak w Ps 37.

21 W w. 38, gdzie również pojawia się czasownik utworzony od rdzenia ברת , ta perspektywa nie jest widoczna. 
ści sprawiedliwych, interpretować informacje o zniszczeniu bezbożnych przede wszystkim jako takie, które mówią o „wycięciu” z ziemi zabezpieczającej utrzymanie, co może być połączone z ciężką sytuacją egzystencjalną, a nawet stanowić zagrożenie dla życia ${ }^{22}$.

Unicestwienie bezbożnych jest przez autora Ps 37 opisane także przy pomocy czasowników pochodzących od rdzeni אבר (w. 20) oraz (w. 38 23). Pierwszy czasownik mówi dosłownie o tym, że bezbożni ,zginą”, chociaż brak jest wzmianki o tym, kto spowoduje ów los niegodziwych. Teksty biblijne uważają Boga za sprawcę czynności opisywanej przez pochodne rdzenia אבד, nie mówią jednak o tym wprost. W świetle literatury mądrościowej i naznaczonych jej wpływem psalmów „zginie” ten, kto działa bezbożnie (np. Ps 1,6; 73,27; Prz 11,10; 28,28). Niejednokrotnie pochodne rdzenia אבר występują w Starym Testamencie razem ze wzmianką o ziemi, co w przypadku Izraela łączy się z karą wygnania (np. Pwt 4,26; 11,17; Joz 23,13.16; Jr 27,10) ${ }^{24}$.

Czasownik utworzony od rdzenia שמר (idea zniszczenia, usunięcia) pojawia się w ramach końcowej wzmianki Ps 37 o tragicznej przyszłości bezbożnych (w. 38). Dana okoliczność jest wyrazem typowego dla pochodnych osnowy שמד zjawiska występowania na ostatnim miejscu względem innych czasowników, których działalność dotyczy tego samego przedmiotu w ramach jednego tekstu. Ma to na celu podkreślenie końcowego tragizmu tego, co się wydarzyło, bądź ma pełnić funkcję swoistego podsumowania w stosunku do wcześniej przedstawionych działań destrukcyjnych. Rzecz interesująca, że przedmiotem zniszczenia, o którym informuje rdzeń שמר, jest w tekstach biblijnych przede wszystkim człowiek. Przy czym nie tylko wymiar fizyczny osoby ludzkiej wchodzi w tym przypadku w grę. Idea, którą skrywa w sobie osnowa to idea zniszczenia i zabicia, ale również - w niektórych przypadkach - definitywnego i nieodwracalnego zerwania więzi między przodkami oraz potomkami, które jest wynikiem np. zabicia dziedzica czy całej rodziny, bądź wygnania rodziny z szeroko pojętego domu, będącego jej dziedzictwem (np. 2 Sm 14). Owo „usunięcie” ew. „zgładzenie” może dotyczyć zwłaszcza rodzin, np. dynastii królewskich, a nawet całego narodu. W tekstach starotestamentowych podkreśla się między innymi fakt zerwania więzi tego, kto jest przedmiotem działań opisanych przez czasowniki pochodzące od rdzenia שמר, z ziemią jako przedmiotem dziedzictwa, czego wyrazem jest częste występowanie pochodnych omawianej osnowy w łączności

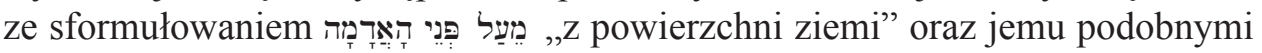

22 Zob. Goldingay, Psalms 1-41, 522, 529.

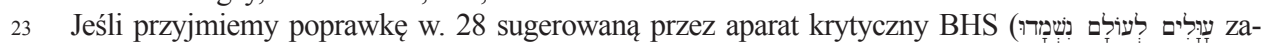

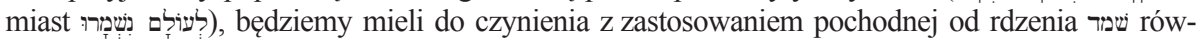
nież w w. 28. Za poprawką tekstu masoreckiego opowiada się między innymi N. Lohfink. Zob. N. Lohfink, שמישר šmd destroy, remove", TDOT, XV 177-178. 
(np. Pwt 6,15; 28,63; Joz 25,15; $1 \mathrm{Krl} 13,34)^{25}$. W ramach Ps 37 jest mowa o definitywnym i całkowitym wyniszczeniu bezbożnych, co wiąże się także ze zniszczeniem, mówiąc dosłownie, „wycięciem” ich potomków (w. 38). Absolutnie nikt oraz nic po nich nie pozostanie.

Oprócz wzmianek o zniszczeniu w Ps 37 pojawiają się obrazy pustego miejsca, które wcześniej było zajęte przez bezbożnego. Potwierdzają one nieobecność bezbożnych, którą sugerowały czasowniki opisujące ich zniszczenie. W świetle wersetów, które te obrazy zawierają, bezbożny po prostu znika, staje się nieobecny.

W w. 10 autor mówi o nieobecności bezbożnych, która nastąpi już niebawem

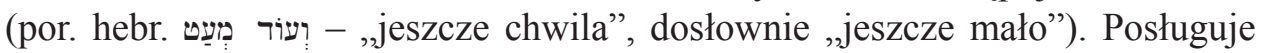
się przy tym typową dla wyrażenia informacji o nieistnieniu czegoś w języku

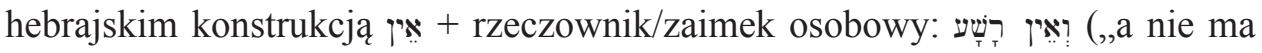

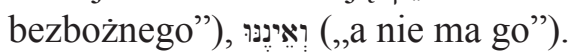

Wersety 35-36 przedstawiają niewythumaczalną, a zarazem bezsporną nieobecność bezbożnego, której doświadczył autor Ps 37 i o której chce pouczyć swojego adresata, porównując niegodziwego do dzikiego drzewa z dużą ilością liści ${ }^{26}$, które $\mathrm{w}$ pewnym momencie po prostu znika z oczu, jakby przestając ist-

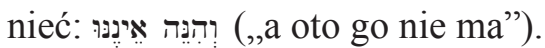

O niechlubnym losie ludzi należących do kategorii bezbożnych, mówi także obraz polnej trawy, dosłownie „ozdoby pastwisk”, która w przyszłości zmieni się w dym. Do niej porównuje autor w w. 20 bezbożnych, dwukrotnie opisując przy

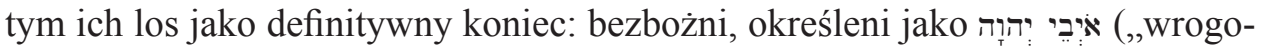
wie Jhwh”), w pewnym momencie po prostu „dojdą do kresu”, dosłownie „skończą się" (hebr. כָָּ)

Z obrazem ulotności, przemijalności czy też krótkotrwałości bezbożnych mamy do czynienia również w w. 2 analizowanego psalmu, gdzie hagiograf stwierdza, że złoczyńców spotka los szybko więdnącej trawy bądź wyschniętej świeżej zieleni ${ }^{27}$.

25 Zob. Lohfink, שמדר šmd destroy, remove”, 179, 181, 182-184.

26 Tłumaczenie w. 35 pozostaje przedmiotem dyskusji wśród egzegetów. Proponowane są poprawki większości słów tegoż wiersza w oparciu o wersję Septuaginty. Zmiana hebrajskiego tekstu jednak nie jest konieczna. Zachowanie wersji zawartej w masoreckim tekście przy jednoczesnym uwzględnieniu podstawowego znaczenia rdzenia ערה hitpael pozwala na następujące thumaczenie: ,widziałem bezbożnego groźnego i rozciągającego się (rozrastającego się) jak dzikie bujne drzewo”. Jako

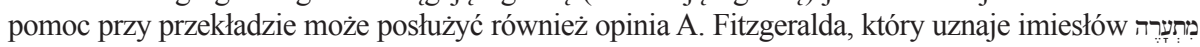

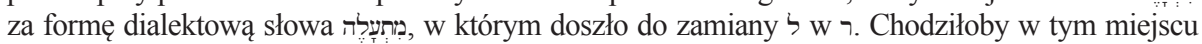
o pochodną rdzenia עלה, który może być wykorzystany także do opisu czynności rośnięcia roślin i drzew. Zob. A. Fitzgerald, “The Interchange of L, N and R in Biblical Hebrew”, JBL 97 (1978) 486. Cyt. za Craigie, Psalms 1-50, 296. Biorąc pod uwagę sugestię A. Fitzgeralda powstałby następujący przekład w. 35: „widziałem bezbożnego groźnego i wynoszącego się jak dzikie bujne drzewo”.

27 Obraz trawy, która szybko wysycha, jest niejednokrotnie stosowany w tekstach biblijnych (np. Ps 90,5-6; 103,15; 129,6). Zob. Goldingay, Psalms 1-41, 519. 
Biorąc pod uwagę kontekst, w jakim umieszczono wzmianki o zniszczeniu bądź zniknięciu bezbożnego, można stwierdzić, że autor stosuje je w różnych sytuacjach. W początkowych wersetach Ps 37 twierdzenie o szybkim zniknięciu bezbożnych bądź ich „wycięciu” ma przekonać adresata utworu, by nie płonął przeciw nim gniewem oraz nie żywił w stosunku do nich zazdrości (w. 2.9.10). Bezbożnych bowiem oczekuje szybki kres. Już w pierwszej części Ps 37 dochodzi także do konfrontacji tragicznego losu bezbożnych z tym, co oczekuje sprawiedliwych (w. 10). W kolejnych częściach utworu wzmianka o losie bezbożnych pojawia się kilkakrotnie w wyraźnym kontraście do twierdzeń mówiących o przyszłości sprawiedliwych. Podczas gdy bezbożni zginą, ci, którzy należą do kategorii sprawiedliwych (zob. 3.1.), staną się właścicielami ziemi. W świetle w. 34 zniszczenie bezbożnych pójdzie w parze z wywyższeniem adresata psalmu. Na tle owych, kontrastowych w swojej wymowie twierdzeń o losie bezbożnych i sprawiedliwych, niegodziwi jawią się jako ludzi kompletnie przegrani, nie mający żadnej przyszłości.

O bezbożnych jako tych, którzy są zagrożeniem dla sprawiedliwych i ich życia, autor Ps 37 wspomina w kilku miejscach. Najpierw w w. 12 przedstawia czytelnikowi bezbożnego jako knującego zło (por. w. 7$)^{28}$ i zgrzytającego zęba$\mathrm{mi}^{29}$. Następnie w w. 14, posługując się obrazem człowieka wyciągającego miecz oraz strzelca mierzącego do prawych i ubogich z łuku w celu ich zabicia (zob. występowanie w analizowanym wierszu złożenia לִ pochodzącego od rdzenia טבח ,zamordować”, ,zmasakrować”) ${ }^{30}$, w sposób plastyczny mówi już o bardzo konkretnym niebezpieczeństwie, jakie czyha na sprawiedliwego z ręki bezbożnego. O tym samym doświadczeniu bezpośredniego zagrożenia dla życia sprawiedliwego ze strony niegodziwego (zob. występowanie w analizowanym wierszu

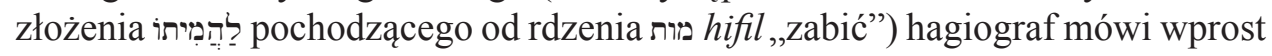
w ramach w. 32. W świetle całego Ps 37 właśnie wzmianki o działaniu bezbożnego w stosunku do sprawiedliwego są twierdzeniami, które przybliżają naturę

28 W w. 12 na określenie działania bezbożnego zastosowano imiesłów thóry jest utworzony od rdzenia זמם Zawierającego neutralną ideę planowania (zob. S. Steingrimsson, , זמם zmm plan”, TDOT, IV 88-89). Kontekst występowania tej formy czasownikowej w w. 12 jednoznacznie skłania do interpretowania czynności opisanej za pomocą זמ̣ jako negatywnej w stosunku do sprawiedliwego.

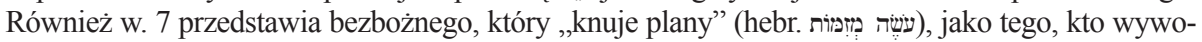
łuje u adresata Ps 37 gniew, co słusznie prowadzi do rozumienia samej czynności planowania jako pejoratywnej.

29 Zdaniem niektórych autorów mamy w tym miejscu do czynienia z obrazem bezbożnego jako drapieżnika (por. Ps 35,16-17). Zob. Hossfeld - Zenger, Die Psalmen I, 235; Kraus, Psalmen 1-59, 441.

30 Jeśli upadek prawych i ubogich wskutek działań bezbożnego (w. 14) może być rozumiany także jako np. spadnięcie wskutek odniesionych ran, to wypowiedź paralelna do twierdzenia o upadku, mianowicie „by zabić tych, których droga jest prosta”, zmusza do interpretacji „upadku” jako czynności pozbawienia życia. Zob. Goldingay, Psalms, 524. Nie chodzi zatem jedynie o niebezpieczeństwo, które sprawiedliwi mogą przezwyciężyć, ale o realne zagrożenie ze strony bezbożnego, które będzie końcem sprawiedliwych. 
bezbożnych, przedstawiając tę grupę przede wszystkim jako działającą na szkodę sprawiedliwych. Biorąc pod uwagę wspomnianą okoliczność staje się zrozumiałe, dlaczego autor, który w w. 35 wykorzystuje obraz dzikiego liściastego drzewa do przedstawienia bezbożnego, charakteryzuje go w pierwszej kolejności za pomocą przymiotnika עִ עִריִ, czyli jako „napawającego grozą”, ,bezwzględnego”, „mocnego", a więc nawet jako swoistego „tyrana”31.

Wszystkim wzmiankom o bezbożnych jako zagrożeniu dla sprawiedliwych towarzyszy przeświadczenie, iż niegodziwym nie udaje się wyrządzić krzywdy swoim oponentom. Ich niecne zamiary nie zostają zrealizowane. Autor biblijny na różny sposób stara się przekonać o tym swojego adresata. W w. 15 odwołuje się do typowo mądrościowego przeświadczenia, że zło człowieka niegodziwego obróci się przeciwko niemu samemu (por. Prz 26,27): miecz, który bezbożny wyciągnie przeciwko ludziom należącym do kategorii sprawiedliwych, przeszyje jego własne serce ${ }^{32}$. Oprócz tego psalmista mówi np. o złamaniu napiętego przez bezbożnego łuku (w. 14-15) bądź o połamaniu ramion grzeszników ${ }^{33}$ (w. 17a). To, kto jest odpowiedzialny za taki los bezbożnych, autor przemilcza. Niektórzy egzegeci jednak dopatrują się we wspomnianych twierdzeniach informacji o Bożym działaniu ${ }^{34}$. Końcowe wersety (w. 32-33.39-40) już wprost przedstawiają Boga jako tego, który przeszkodzi bezbożnym w realizacji ich niecnych zamiarów w stosunku do sprawiedliwych. Dzięki Bożej interwencji fałszywe oskarżenie ze strony bezbożnego nie doprowadzi do uznania sprawiedliwego za winnego oraz do pozostawienia go przez Boga w mocy człowieka grzesznego,

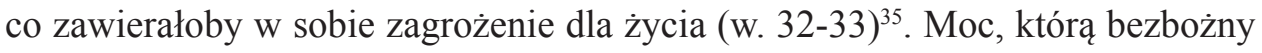

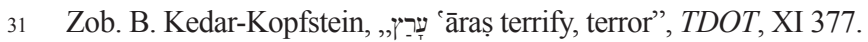

32 H.-J. Kraus mówi w tym miejscu o immanentnym nemezis (zob. także Ps 7,14-17). Zob. H.-J. Kraus, Psalmen 1-59 (Biblischer Kommentar Altes Testament 15/1; Neukirchen-Vluyn: Neulirchener Verlag 2003) 442.

33 Wypowiedź o połamaniu ramion bezbożnych może wskazywać na zakończenie ich bezwzględnego działania. W opinii E. Zengera bowiem „,ramiona bezbożnych“ są metaforą determinacji i bezwzględności, charakteryzujących bezbożnych powielających swe bogactwa. Zob. Hossfeld - Zenger, Die Psalmen I, 236. O tym, że w przypadku informacji z w. 17a chodzi o ustanie działania bezbożnych, mówi również H.-J. Kraus. Zob. Kraus, Psalmen 1-59, 442. Zdaniem J. Goldingaya w. 17a może zawierać ironię i przedstawiać bezbożnych, których ramiona łamią się pod ciężarem posiadanych dóbr. Zob. Goldingay, Psalms, 525.

34 Zob. Oeming, Das Buch der Psalmen, 208. Przypuszczając, że dzień, który nadchodzi dla bezbożnych, może być rozumiany jako „dzień Jhwh”, a więc dzień wielkiego sądu Jhwh nad całym światem, M. Oeming interpretuje informację z w. 15 jako opisującą Boże działanie w stosunku do agresorów występujących przeciwko sprawiedliwym. W przypadku informacji zawartej w w. 17a (ramiona bezbożnych będą połamane) autor suponuje zastosowanie passivum divinum. Na to, że wypowiedź z w. 17a może odnosić się do Bożego działania, wskazuje paralelizm antytetyczny, który występuje w w. 17. Druga część w. 17, w której jest mowa o wspieraniu sprawiedliwych przez Boga, może sugerować, iż połamanie ramion bezbożnych również będzie dokonane przez Pana. Także J. Goldingay przypuszcza, że w. 17a może zawierać informację o Bożym działaniu. Zob. Goldingay, Psalms, 525.

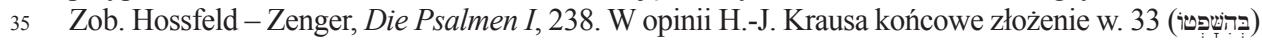
wskazuje na proces sakralny, w skutek którego nieponoszący winy sprawiedliwy miał być uznany za 
zyska nad sprawiedliwym, nie będzie trwała zawsze (w. 39-40). Ponadto analizowany psalm zawiera wzmiankę o tym, że poczynania bezbożnych względem sprawiedliwych wywołają u Boga śmiech, co może być wyrazem przekonania psalmisty o wiedzy Jhwh o tym, że zbliża się dzień zejścia bezbożnych ze świata bądź czas Pańskiego sądu nad nimi (w. 13) ${ }^{36}$.

W świetle powyższych obserwacji bezbożni jawią się czytelnikowi jako ci, którzy doznają porażki na płaszczyźnie relacji bezbożny - sprawiedliwy. Ich zamiary nie zostają zrealizowane, a niegodziwe poczynania względem sprawiedliwych nie przynoszą sukcesu.

Dopełnieniem przedłożonej charakterystyki bezbożnego stają się te miejsca Ps 37, w których jest mowa o jego sytuacji ekonomicznej. Jest rzeczą interesującą, że z jednej strony bezbożny jawi się czytelnikowi jako człowiek majętny, co koresponduje z przekonaniem adresata psalmu o tym, iż bezbożny jest człowiekiem sukcesu (w. 7), z drugiej zaś strony przedstawiono go jako tego, kto nie ma środków do życia: w w. 16 wspomniano dostatek (hebr. המוץ ) bezbożnych, w w. 21 zaś jest mowa o tym, że bezbożny korzysta z pożyczki, ale długu nie oddaje

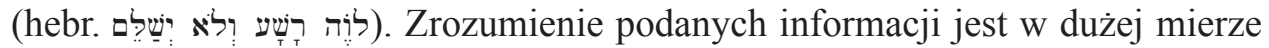
uzależnione od interpretacji znajdujących się w ich bezpośrednim sąsiedztwie zdań, które odnoszą się do sprawiedliwego. Z tego też względu ich wyjaśnienie pojawi się w następnej części artykułu, w której zostanie przedstawiona analiza motywu człowieka sprawiedliwego w Ps 37.

\section{Analiza motywu człowieka sprawiedliwego w Ps 37}

Analizę motywu człowieka sprawiedliwego w Ps 37 zaczniemy od przedstawienia wykorzystanych w omawianym utworze określeń odnoszących się do tej kategorii osób. Zwrócimy uwagę na to, jakie terminy oraz wyrażenia zastosowano w poszczególnych częściach tego psalmu, próbując przy tym wytłumaczyć, co może być powodem takiej strategii autora. Kolejnym krokiem w ramach tego punktu będzie analiza kontekstów występowania określeń odnoszących się do człowieka sprawiedliwego w Ps 37.

winnego. Zob. Kraus, Psalmen 1-59, 443.

36 M. Oeming zwraca uwagę na fakt, iż złożenie î̉, ,jego dzień” z w. 13 nie jest jednoznaczne. Może oznaczać dzień bezbożnego, a więc kres jego ziemskiego życia bądź dzień sądu nad nim. Niewykluczone jest także to, że יis odnosi się do Boga i opisuje dzień Pana jako dzień Bożego sądu. Zob. Oeming, Das Buch der Psalmen, 208. Zdaniem E. Zengera informacje umieszczone w w. 15 można potraktować jako wytłumaczenie wypowiedzi z w. 13 o dniu, który zbliża się do bezbożnego. Zob. Hossfeld - Zenger, Die Psalmen I, 236. 


\subsection{Określenia odnoszące się do człowieka sprawiedliwego w Ps 37}

Hebrajski termin jạִ jako określenie człowieka sprawiedliwego ${ }^{37}$ pojawia się w Ps 37 dopiero w w. 12. W następnych wierszach wystąpi on jeszcze kilka razy, aż wreszcie w w. 39-40 wzmianka o zbawieniu sprawiedliwych zwieńczy cały psalm. Od pierwszego zastosowania w tekście termin „sprawiedliwy” staje się głównym pozytywnym określeniem człowieka (w. 16.17.21.25.29.30.32.39). Obok niego w badanym utworze wykorzystano również inne terminy: „biedny” i „ubogi” (w. 14), „[ci, którzy są] prostej drogi” (w. 14), „nienaganni”/,doskonali” (w. 18), „błogosławieni” (w. 22), „mąż”38 (w. 23), „święci” (w. 28), „niewinny” (w. 37), ,prosty” (w. 37), „człowiek pokoju” (w. 37). Większość z nich pojawia się $\mathrm{w}$ konstrukcjach paralelnych do tych, które zawierają określenie „sprawiedliwy” bądź w podobnych kontekstach ${ }^{39}$. W związku z tym czytelnik zyskuje przeświadczenie, że odnoszą się one do tej samej kategorii osób, która jest nazwana „sprawiedliwymi”, oraz bliżej tłumaczą, co znaczy być sprawiedliwym. W części poprzedzającej pierwsze zastosowanie terminu jest jest ponadto mowa o ludziach, którzy „ufają Jhwh” (w. 9) oraz są „,poniżeni”/,ubodzy”40 (w. 11). Jak jedno, tak i drugie określenie również można odnieść do ludzi sprawiedliwych. Przekonuje o tym kontekst ich występowania, którym jest obietnica posiadania ziemi i jej dóbr, łączona w trzeciej części psalmu z tymi, którzy noszą miano (w. 27).

W tekście Ps 37 jest mowa także o sprawiedliwości (hebr. pجִ chodzi o sprawiedliwość adresata psalmu, która, przy spełnieniu pewnych warunków, może zajaśnieć jak słońce. Jako paralelna w stosunku do sprawiedliwości występuje w tym wierszu rzeczywistość oznaczona przy pomocy hebr. słowa

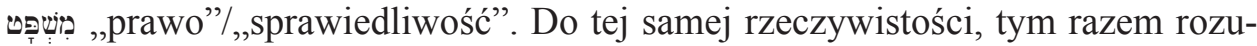

37 Przymiotnik צִָּדיק odnosi się w tekstach biblijnych do ludzi oraz Boga, nigdy, z wyjątkiem Pwt 4,8, nie

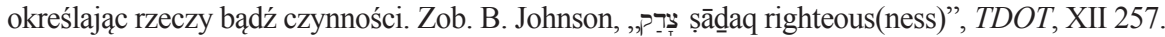

38 Podany polski termin jest thumaczeniem hebrajskiego rzeczownika גבֵּ który w tym miejscu określa człowieka przebywającego w bliskiej relacji z Bogiem (więcej na ten temat w paragrafie 3.2). Wspomniany hebrajski rzeczownik, aczkolwiek odnoszący się w omawianym psalmie ogólnie do człowieka, został przetłumaczony jako „mąż”, by odróżnić go od innego rzeczownika hebrajskiego צ איש שָׁלום z określenia 37), który przetłumaczono jako „,człowiek”.

39 Ps 37,14: „Występni dobywają miecza, napinają swój łuk, by powalić biednego i ubogiego, by zabić tych, których droga jest prosta” (por. w. 12); w. 18: „Pan zna dni nienagannych, a ich dziedzictwo trwać będzie na wieki” (por. w. 29); w. 28: „bo Jhwh miłuje sprawiedliwość i nie opuszcza swoich świętych” (por. w. 17); w. 22 ,ponieważ błogosławieni przez Niego [Boga] posiądą ziemię, przeklęci przez Niego [Boga] będą wycięci (por. w. 29).

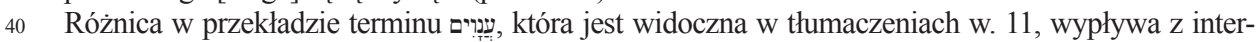

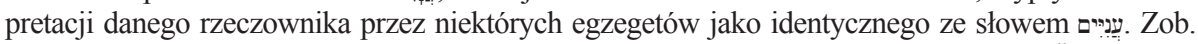
M. Bauks, „«Das Land erben» oder «die Erde in Besitz nehmen» in Ps 36 (37 MT): ein Übersetzungsvergleich”, Die Septuaginta. Texte, Kontexte, Lebenswelten. Kongressakten der Internationalen Tagung Wuppertal, 20.-24.07.2006 (red. M. Karrer-W. Kraus) (Wissenschaftliche Untersuchungen zum Neuen Testament 219; Tübingen: Mohr Sieback 2008) 503. 
mianej jako przedmiot Bożego upodobania, odwołuje się autor również w w. 28,

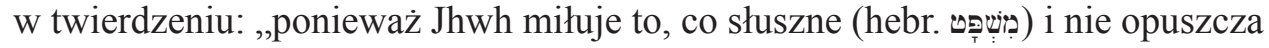
swoich świętych/pobożnych". W świetle w. 30 מִ charakteryzuje zaś mowę sprawiedliwego jako mędrca.

Termin בֶּריק, jako główne określenie odnoszące się do człowieka sprawiedliwego, pojawia się wyłącznie w drugiej i trzeciej części Ps 37. W ramach drugiej części wszędzie, z wyłączeniem w. 25, który ma charakter autobiograficznego podsumowania, występuje w ścisłej łączności z terminem רָָ Warto zauważyć, że właśnie w ramach w. 12-26 po raz pierwszy dochodzi do „wyniesienia” sprawiedliwego nad bezbożnego (w. 16). W części końcowej oprócz konfrontowania postaci sprawiedliwego z bezbożnym dokonuje się identyfikacji sprawiedliwego z mędrcem, który żyje Prawem Bożym.

W pierwszej części Ps 37, gdzie kluczowy dla badanego utworu termin צְִּדיק nie występuje, pojawiają się, przy czym zawsze w kontekście obietnicy dysponowania ziemią $\mathrm{w}$ przyszłości, określenia, które uwypuklają postawę ufności

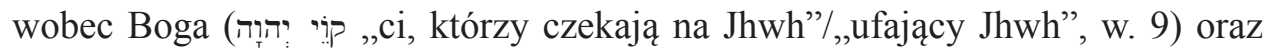

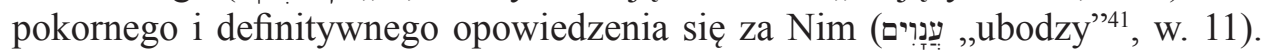
Stosowanie tych właśnie określeń w kontekście nawoływań adresata do skupienia się na Bogu i ufności wobec Niego (w. 3a.4a.5a) jest zrozumiałe. Obietnica ziemi dla tych, którzy zawierzyli Jhwh, nie zważając na ekonomiczną bądź spo-

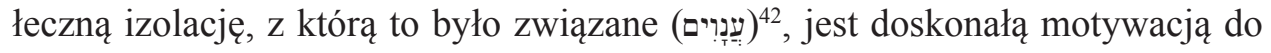
kształtowania w sobie postawy ufności wobec Boga. Jest to droga do tego, by sprawiedliwość adresata psalmu „stała się jak światło” (w. 6).

W drugiej części Ps 37, która nie tylko wyraźnie zestawia ze sobą „,sprawiedliwego" i „bezbożnego”, ale również podkreśla ich bezpośrednią interakcję, obok

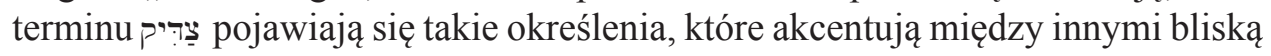
relację ludzi należących do kategorii sprawiedliwych z Bogiem (בְּ?

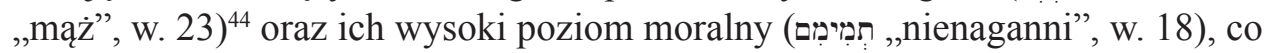
pociąga za sobą przychylność ze strony Jhwh (w. 18-19.23-24).

W ostatniej części Ps 37 słownictwo wykorzystane dla określenia sprawiedliwego pozwala adresatowi widzieć w nim człowieka o wysokim poziomie religijności (חָסִידָיר ,jego pobożni”, w. 28), zaś tego, kto jest nienaganny w sensie moral-

41 Zob. Hossfeld - E. Zenger, Die Psalmen I. Psalm 1-50, 235.

42 Zob. Hossfeld - E. Zenger, Die Psalmen I. Psalm 1-50, 235.

43 Zob. H. Kosmala, ,בָּבָּר gābhar strength, hero", TDOT, II 377, 378-379.

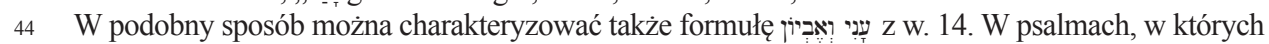

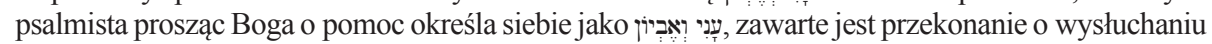

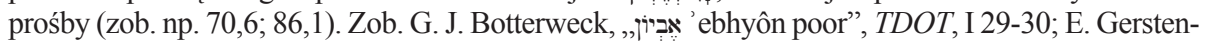

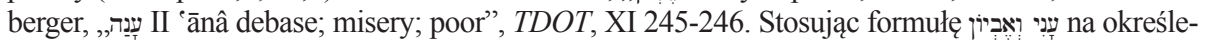
nie tych, którzy doświadczają na sobie wrogości bezbożnych (w. 14), autor analizowanego Psalmu pośrednio informuje czytelnika o tym, iż dana sytuacja z pewnoscią ulegnie zmianie wskutek Bożej interwencji. 


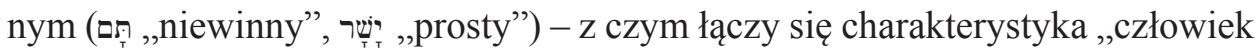
pokoju" (איש שָלום) - za absolutny model zachowania dla adresata psalmu (w. 37).

\subsection{Analiza kontekstów występowania określeń odnoszących się do człowieka sprawiedliwego w Ps 37}

Przy analizie wzmianek o sprawiedliwym z Ps 37 zauważamy, iż jego charakterystyce oraz opisaniu jego losu poświęca się w tekście dużo miejsca. Nie sposób nie dostrzec także różnorodności określeń synonimicznych, które, obok kluczowego terminu, pojawiają się na oznaczenie sprawiedliwego. Pokazują one, co znaczy być sprawiedliwym, a także to, jaką drogą trzeba kroczyć, by sprawiedliwość osiągnąć bądź jej nie stracić.

Pierwszym rzucającym się w oczy kontekstem wzmianek o sprawiedliwych są te miejsca Ps 37, w których jest mowa o ich przyszłym losie. Psalmista niejednokrotnie wspomina także o zagrożeniu dla ich życia, pochodzącym od bezbożnych (w. 12.32.39-40 ${ }^{45}$ ), przy czym często obok tego typu twierdzeń, ale również niezależnie od nich, znajdują się wypowiedzi podkreślające Bożą ocalającą działalność względem sprawiedliwych oraz mówiące o opiece, jaką Jhwh nad nimi roztacza. Ponadto psalmista mówi o ich sytuacji ekonomicznej. W Ps 37 spotkamy się również z charakterystyką sprawiedliwego jako mędrca. Ostatnim kontekstem, z którego możemy czerpać informacje o człowieku sprawiedliwym, są wzmianki o sprawiedliwości.

W analizowanym tekście kilkakrotnie napotykamy twierdzenia dotyczące przyszłego losu sprawiedliwych. Tworzy je przede wszystkim obietnica, że ci, którzy należą do kategorii sprawiedliwych, posiądą ziemię ${ }^{46}$. O przyszłym dysponowaniu ziemią autor wspomina pięciokrotnie (w. 9.11.22.29.34), z czego w czterech miejscach mówi o tym, co będzie udziałem sprawiedliwych, a w w. 34 odnosi się do tego, co może stać się rzeczywistością w życiu jego adresata. W w. 9.11.22.29 autor przedstawia los sprawiedliwych za pomocą sformułowania

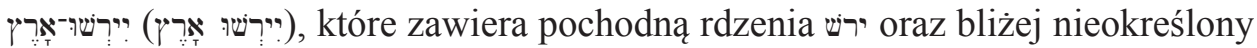

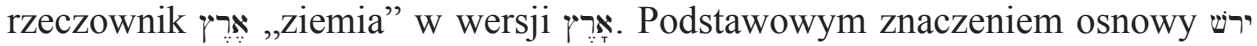
jest „wzięcie [czegoś] w posiadanie”, co może być np. skutkiem wcześniejszego podboju bądź dziedziczenia ${ }^{47}$. Rzeczownik ארץ możemy odnieść zaś do ziemi jako

45 Do tej grupy wypowiedzi trzeba także zaliczyć opis postępowania bezbożnego zawarty w w. 14, gdzie jako adresaci jego działań są wspomniani „,biedni” i ,ubodzy” oraz ci, którzy idą prostą drogą.

46 Żaden z psalmów biblijnych nie poświęca tyle uwagi problematyce ziemi, co Ps 37. Zob. K. Liess, „«Die auf JHWH hoffen, werden das Land besitzen« (Psalm 37,9). Zur Landthematik in den Psalmen”, Heiliges Land (red. M.-Th. Wacker - R. Koerrenz) (Jahrbuch für Biblische Theologie 23; Neukirchen-Vluyn: Neukirchener Verlag, 2009) 58.

47 Pochodne rdzenia רש $q$ qal, stosowane z obiektem nieożywionym, mogą, w zależności od kontekstu występowania oraz czasu powstania tekstu, w którym się pojawiają, mieć znaczenie „wziąć w po- 
określonego terenu geograficznego (kraj), interpretować jako termin na oznaczenie całego świata albo uważać za słowo opisujące ziemię uprawną ${ }^{48}$. W tradycji starotestamentowej ten rzeczownik miał również niezmiernie ważne znaczenie teologiczne jako termin odnoszący się do ziemi Izraela, obiecanej przez Boga praojcom, danej ich potomkom oraz odebranej następnie Izraelowi wskutek jego grzechu $^{49}$. W tradycji deuteronomistycznej często stosowano zaś syntagmę ירש אריץ dla przedstawienia wydarzenia podboju przez Izraelitów Ziemi Obiecanej

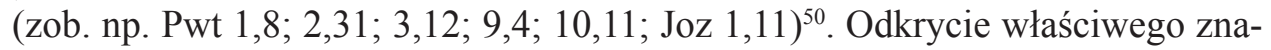
czenia rzeczownika אריץ w analizowanym utworze, a więc i zrozumienie tego, jaka będzie przyszłość sprawiedliwych, jest w pierwszej kolejności uzależnione

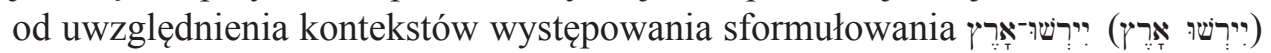
w Ps $37^{51}$, a także wzięcia pod uwagę wszystkich miejsc zastosowania terminu אִר w analizowanym tekście ${ }^{52}$. W Ps 37 pojawia się także twierdzenie, że dzie-

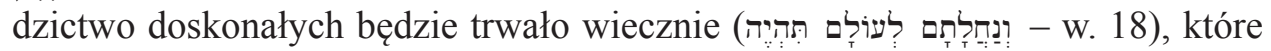

siadanie”, ,zdobyć”/,zawładnąć” (w skutek podboju), być właścicielem”/,cieszyć się z posiadania” (łączy się z obiektem ,ziemia”) bądź „odziedziczyć” (późne teksty powygnaniowe). „Branie w posiadanie" jest podstawową ideą, która jest skryta w rdzeniu יר qal, występującym w konstrukcji

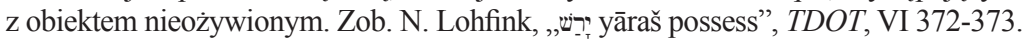

48 Zob. M. Ottoson - J. Bergman, אריץ 'erets land", TDOT, I 393, 394-401.

49 Zob. Ottoson - Bergman, אריץ 'erets land", TDOT, I 401-405. W takim znaczeniu, jako odnoszący się do ziemi Kanaan, rozumie termin ארֵ z Ps 37 np. M. D. Vander Hart. Zob. M. D. Vander Hart, „Possessing the Land as Command and Promise”, MJT 4/2 (1988) 140, 141,146, 150. Według M. Bauks z podobną interpretacją mamy do czynienia u większości biblistów. Wśród innych możliwości rozumienia rzeczownika ארץ z Ps 37 autorka wspomina koncepcję społeczną (ziemia jest obiecana wiernym Jhwh, którzy w chwili obecnej są jej pozbawieni) bądź eschatologiczną. Zob. Bauks, „«Das Land erben» oder «die Erde in Besitz nehmen» in Ps 36 (37 MT): ein Übersetzungsvergleich”, 514-515.

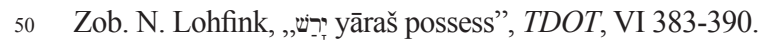

51 Syntagma ירש אריץ występuje w Psałterzu oprócz Ps 37 również w Ps 25,13 oraz 44,4. W przypadku ostatniego tekstu, który nawiązuje do wydarzenia zajęcia przez Izraelitów Kanaanu, mamy do czynienia z wykorzystaniem deuteronomistycznej terminologii (zob. gra słowna form czasownikowych ירט quil hif i w w. 3 i 4, por. np. Pwt 9,3-5; 11,23; 18,12; Joz 23,5. Zob. Hossfeld - Zenger, Die Psalmen I. Psalm 1-50, 275). Kontekst zastosowania syntagmy w Ps 44 jest odmienny od tego, w którym pojawia się ona w Ps 37 (ziemię z Ps 44 czytelnik bez problemu identyfikuje z Kanaanem, podczas gdy w Ps 37 nie ma żadnego wyraźnego odniesienia do Ziemi Obiecanej). Stąd też koncepcja ziemi obecna w Ps 44 nie może być uznana za wystarczającą dla interpretacji obietnicy ziemi z Ps 37. W Ps 25 wzmianka o posiadaniu ziemi występuje w podobnym do Ps 37 kontekście obietnicy: ziemię mają posiąść na własność potomkowie „bojącego się Pana” (w. 12-14). W odróżnieniu od analizowanego psalmu Ps 25 zawiera tylko jedną zapowiedź posiadania ziemi. Egzegeci zwracają uwagę na mądrościowy charakter wierszy, w których występuje obietnica ziemi (por. mądrościowy charakter Ps 37), wskazując zarazem przy charakterystyce utworu na jego późniejszy w stosunku do Ps 37 czas powstania (zob. Hossfeld - Zenger, Die Psalmen I. Psalm 1-50, 162, 166), co w konsekwencji prowadzi do uznania Ps 37 za punkt odniesienia dla Ps 25, między innymi przy interpretacji obietnicy posiadania ziemi.

52 Oprócz tych wierszy Psalmu, w których termin אריץ ,ziemia” występuje w konstrukcji z pochodnymi rdzenia ירש qal (w. 9.11.22.29.3 4), pojawia się on jeszcze w w. 3 w łączności z czasownikiem utworzonym od osnowy. שכן 
najprawdopodobniej również odnosi się do ziemi ${ }^{53}$. Zastosowano w nim bowiem termin נֵַחלָלה ,dziedzictwo", który występuje w tekstach biblijnych w odniesieniu do ziemi Izraela (zob. np. $1 \mathrm{Krl} \mathrm{8,36;} \mathrm{Ps} \mathrm{105,11;} \mathrm{Ez} \mathrm{47,14),} \mathrm{chociaż} \mathrm{może}$ oznaczać także majątek ruchomy i nieruchomy (w tym np. sługi, stada zwierząt, pieniądze), odziedziczony przez określonego członka rodziny w ramach konkretnej rodziny bądź rodu ${ }^{54}$. Rzeczownik נְחלְלָה charakteryzuje rzeczywistość, do której się odnosi, jako coś, czym rodzina bądź klan dysponują w sposób trwały, bez możliwości oddania tego obiektu w posiadanie innego rodu ${ }^{55}$. Wydaje się, że za pomocą wspomnianego rzeczownika autor potwierdza w w. $18 \mathrm{~b}$ absolutną trwałość dziedzictwa nienagannych, a więc najprawdopodobniej to, że będą oni na stałe dysponować ziemią.

Jak należy rozumieć twierdzenie, iż sprawiedliwi posiądą ziemię? O jaką ziemię chodzi psalmiście? Z czym łączy się obietnica ziemi dla sprawiedliwego? Autor natchniony tylko w dwóch miejscach w ramach całego Ps 37 uściśla, jakie znaczenie będzie miało posiadanie ziemi dla sprawiedliwego. Pierwszym z nich jest w. 11, który mówi, że ,ubodzy posiądą ziemię i będą się rozkoszować wielkim pokojem". W tekście hebrajskim pojawia się w tym miejscu rzeczownik שִ שָלום ,pokój”. Termin ten nie oznacza wyłącznie braku wojny, ale zawiera w sobie szeroko pojętą ideę bezpieczeństwa, kompletności, szczęścia, w tym także dobrobytu i pomyślności. שִ to szczyt pragnień oraz oczekiwań społeczno-politycznych człowieka, a także, biorąc pod uwagę nieodłączność sfery religijnej i świeckiej w starożytnym Izraelu, kwintesencja błogosławieństwa Bożego $^{56}$. W świetle niektórych psalmów rzeczywistość określona za pomocą rzeczownika שָׁל wraz ze sprawiedliwością tworzy podstawę istnienia świata (Ps 72,3.7; 85,11). W literaturze mądrościowej, a także w tych miejscach Psałterza, które wykazują znaki wpływu sapiencjalnego, שׁ występuje jako termin na oznaczenie dobrobytu i powodzenia (Ps 73,3; 119,165; Prz 3,2.17; zob. również Lam 3,17$)^{57}$. Tak rozumiany pokój staje się udziałem człowieka, który chodzi drogami mądrości oraz miłuje Prawo Jhwh. W świetle Ps 37 ów szeroko pojęty pokój jest tym, w czym będą się rozkoszować ubodzy, z czego właśnie oni będą

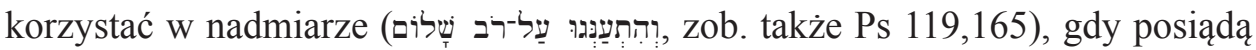
ziemię na własność ${ }^{58}$. Warto przywołać w tym miejscu zapowiedzi przymierza

53 Zob. Alonso Schökel - Carniti, I Salmi, 642; Hossfeld - Zenger, Die Psalmen I, 236; Oeming, Das Buch der Psalmen, 206; Goldingay, Psalms 1-41, 525; Grogan, Psalms, 92; Liess, „ "Die auf JHWH hoffen, werden das Land besitzen « (Psalm 37,9). Zur Landthematik in den Psalmen”, 59.

54 Zob. E. Lipiński, , נָח nāḥal inherit”, TDOT, IX 326, 328-329.

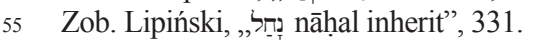

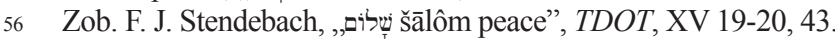

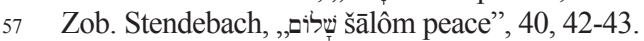

58 Ziemię należy w tym kontekście, jak również w pozostałych wersetach w Ps 37, które zawierają jej obietnicę dla sprawiedliwych/adresata psalmu, rozumieć jako metaforę stanu szczęścia w najszerszym tego słowa znaczeniu, łącznie z jego wymiarem religijnym. M. Bauks podkreśla, że w przypad- 
pokoju, ściśle złączonego z ziemią Izraela, które występują w Księdze Ezechiela $(34,25-30 ; 37,26-28)^{59}$. Pojawiają się one w kontekście wyroczni zbawienia dla Izraela, umieszczonych w Ez 34-37. Istotną cechą tego przymierza jest obecność Jhwh pośród swojego ludu. To ona ma zapewnić Izraelitom שִ we wszystkich sferach życia. To ona tworzy istotę przymierza w odrodzonej ziemi Izraela ${ }^{60}$. W analizowanym psalmie spotykamy się z podobnym przeświadczeniem przeniesionym wszakże na płaszczyznę indywidualną oraz jakby wyjętym z konkretnego kontekstu geograficznego. Adresat Ps 37 jest wezwany do tego, by miał radość z Jhwh, dosłownie „doznawał przyjemności”/,rozkoszował się” (hitpael od ענג (w. Nim (4a). Motywacją do kształowania w sobie takiej postawy jest zaś zapowiedź, iż „ubodzy posiądą ziemię i będą się 'rozkoszować' (hitpael od ענג) wielkim pokojem" (w. 11).

Przyszły los sprawiedliwych wypełniony takim doświadczeniem jawi się jako wielka wygrana, szczególnie na tle życiowej porażki, jaka oczekuje bezbożnych. W w. 29 autor biblijny dodaje, że posiadanie ziemi przez sprawiedliwych będzie miało charakter trwały. Sprawiedliwi nie tylko zyskają ziemię na własność, ale

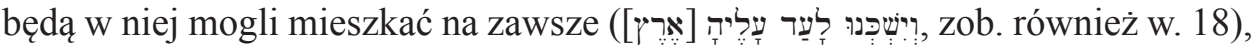
co, biorąc pod uwagę ideę skrytą w rdzeniu שכן (idea zamieszkiwania), oznacza, iż zyskają taką przestrzeń życiową, która im na trwałe zapewni bezpieczeństwo ${ }^{61}$. Owo przeświadczenie potwierdza myśl o przyszłym rozkoszowaniu się w ziemi pokojem z w. 11. Także w. 37 odnosi się do końcowych losów sprawiedliwych, konstatując w sposób lakoniczny, że przyszłość będzie ich udziałem: „przyszłość należy do ludzi pokoju" ${ }^{2}$. Zdaniem niektórych egzegetów także w tym twierdzeniu mamy do czynienia z obietnicą, iż sprawiedliwi odziedziczą ziemię

ku ,ziemi” z Ps 37 mamy do czynienia z toposem teologicznym wykorzystywanym dla potwierdzenia ważności przekonania o charakterze mądrościowym o zależności między działaniem człowieka i jego losem. Zob. Bauks, „«Das Land erben» oder «die Erde in Besitz nehmen» in Ps 36 (37MT). Ein Übersetzungsvergleich", 518. Na to, że tak często występująca w omawianym psalmie konstrukcja ירש ארץ może mieć również inne niż konkretne znaczenie (deuteronomistyczna koncepcja zajęcia ziemi Kanaan) oraz odnosić się do doświadczenia zbawienia, zwrócił uwagę już N. Lohfink. Zob. Lohfink, ,ִיָ- yāraš possess", 394.

59 Szczegółowa analiza zapowiedzi przymierza pokoju w Księdze Ezechiela znajduje się w publikacji W. Pikor, Rola ziemi w przymierzu Boga z Izraelem (Wydawnictwo KUL: Lublin 2013) 275-283. Funkcji ziemi w nowym przymierzu jest poświęcony cały drugi punkt drugiego rozdziału monografii (s. 261-283).

60 Zob. Pikor, Rola ziemi w przymierzu Boga z Izraelem, 282.

61 W tekstach biblijnych pochodne rdzenia שכ niejednokrotnie stosowane są wtedy, gdy chodzi nie tyle o podkreślenie przebywania na jakimś określonym terytorium, ale o poinformowanie o bezpiecznej egzystencji jako takiej (zob. np. 2 Sm 7,10; Iz 33,16; Ps 16,9; 69,36-37). Jest to najbardziej zauważalne w tych tekstach, w których obok czasowników utworzonych od osnowy nie pojawiają się żadne okoliczniki miejsca (zob. np. Ps 102,29; zob. także 37,27). Chodzi w tym przypadku o taką egzystencję, która jest wynikiem Bożej opieki. Zob. M. Görg, ,ןָָָ šāknan settle, dwell”, TDOT, XIV 696-698.

62 Odmienne thumaczenie tej części w. 37 proponuje B.T. Tanner: „for the end of this one is peace”. Zob. Declaisse-Walford - Jacobson - Tanner, The Book of Psalms, 352. 
oraz będą doświadczać bezpieczeństwa ${ }^{63}$. Wydaje się jednak, że słowo אַח ma ma w tym miejscu raczej znaczenie ,przyszłości”, chociaż nie jest wykluczone, że może się odnosić również do potomstwa sprawiedliwych ${ }^{64}$. W odróżnieniu od sprawiedliwych bezbożni są ludźmi bez przyszłości (por. Prz 24,20), ponieważ zarówno oni sami, jak i ich potomstwo znikną/będą zniszczeni (zob. Ps 37, 2.9.10.22.28.34.35-36.38).

Z odniesieniem do mieszkania w ziemi jako swoistego zwieńczenia losu człowieka mamy do czynienia również w w. 3 i $27^{65}$. W tych przypadkach nie chodzi jednak o ziemię, którą będą dysponować sprawiedliwi, ale o przestrzeń, która stanie się miejscem pobytu adresata Ps 37, gdy ten będzie ufał Bogu, czynił dobro oraz stronił od zła. W podobnym świetle, jako skutek konkretnej postawy moralnej, charakteryzującej się określonym stosunkiem do Boga, przedstawia przyszłe posiadanie ziemi przez adresata Ps 37 wypowiedź z w. 34 .

W świetle Ps 37 obietnica posiadania ziemi przez sprawiedliwych nie jest zwykłą wypowiedzią o ich przyszłym losie, ale ma głównie charakter zachęty skierowanej do adresata psalmu do bycia sprawiedliwym. O tym, że człowiek sprawiedliwy, ze wszystkim co się z tym wiąże (zob. liczne określenia synonimiczne terminu wprost w. 37: „Obserwuj (dosłownie „strzeż”) niewinnego, przyjrzyj się prawemu, ponieważ przyszłość należy do ludzi pokoju”.

$\mathrm{Z}$ odniesieniem do przyszłych losów sprawiedliwego mamy do czynienia także w w. 19.24.31.33 oraz, być może, w w. 26 i 40. Biorąc pod uwagę fakt, że zajmujące nas twierdzenia występują we wspomnianych wierszach w łączności $\mathrm{z}$ informacjami o bliskiej relacji sprawiedliwego z Jhwh bądź w ramach jego charakterystyki, zinterpretujemy wypowiedzi odnoszące się do przyszłości sprawiedliwych przy omówieniu odnośnych tematów.

Przy analizie motywu sprawiedliwego w Ps 37 nie sposób nie zauważyć drugiego ważnego kontekstu występowania wzmianek o ludziach należących do kategorii sprawiedliwych. Tworzą go te miejsca badanego utworu, w których jest mowa o zagrożeniu dla sprawiedliwych, pochodzącym od bezbożnych

63 Zob. Goldingay, Psalms 1-41, 532.

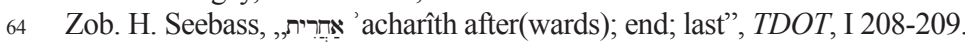

65 W świetle w. 27 nie ma mowy wprost o ziemi, ale podobieństwo między w. 3 i 27, w których obecne

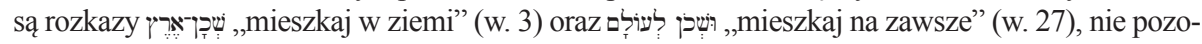
stawia wątpliwości, że również w przypadku wypowiedzi z w. 27 chodzi o egzystencję (zob. wcześniejsze wythumaczenie znaczenia rdzenia שכ), która jest związana z bliżej nieokreśloną ziemią. W

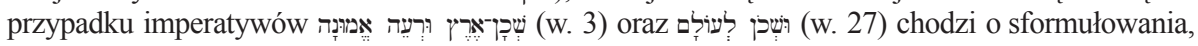
które mają charakter celowy - podkreślają to, co stanie się udziałem adresata psalmu, jeśli ten dostosuje się do rad wyrażonych za pomocą występujących wcześniej zdań rozkazujących: „Miej ufność w Bogu i czyń dobro, [a wtedy] będziesz mieszkać w ziemi i przestrzegać wierności” (w. 3), „Odwróć się od zła, czyń dobro, [a wtedy] będziesz mieszkać na wieki”. Zob. Alonso Schökel - Carniti, I Salmi, 644. 
(w. 12.14.32.40). W świetle Ps 37 sprawiedliwi nigdy nie stają się ofiarą przemocy albo knowań bezbożnych. Autor niejednokrotnie podkreśla, że tym, komu sprawiedliwi zawdzięczają swój ratunek jest Bóg. To On wyzwala sprawiedli-

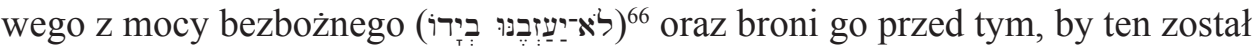

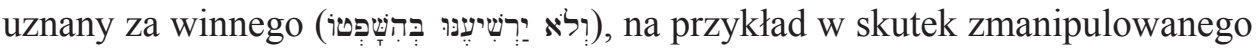
procesu sądowego ${ }^{67}$ (w. 32-33, zob. także w. 14-15). W świetle końcowej, a więc wieńczącej cały utwór wypowiedzi, sprawiedliwi są przedstawieni jako ci, którzy niewątpliwie doświadczą, bądź już doświadczają, Bożego ratunku z rąk bezbożnych (w. 40). Na określenie Bożej czynności zbawczej zastosowano w niej aż cztery czasowniki pochodzące od trzech synonimicznych rdzeni hebrajskich

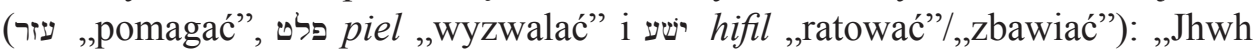

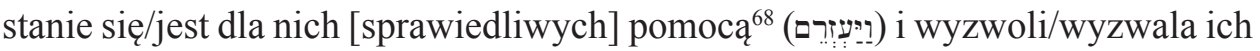

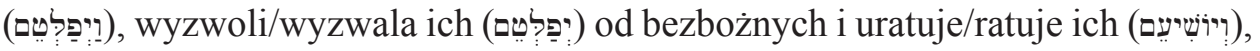
ponieważ uciekają się do Niego" (w. 40) ${ }^{69}$.

W świetle Ps 37 sprawiedliwi nie tylko doświadczają Bożego ratunku w sytuacji zagrożenia ze strony bezbożnych, ale także są przedmiotem szczególnej troski Boga oraz Jego błogosławieństwa w ciągu całego swojego życia. W w. 17 jest mowa o Jhwh, w którym sprawiedliwi znajdują oparcie. Na oznaczenie Bożej działalności występuje w nim imiesłów ספוֹ, utworzony od rdzenia który w koniugacji qal zawiera ideę wspierania, podtrzymywania, pomagania. W konstrukcji 7 7 + biernik, która występuje w w. 17, pochodne rdzenia 7מ mogą mieć tak dosłowne, jak i przenośne znaczenie. W omawianym wersecie mamy do czynienia ze znaczeniem przenośnym: Jhwh staje się dla sprawiedliwego pomocą, podczas gdy/dlatego też „ramiona bezbożnego [którego działanie zagrażało egzystencji sprawiedliwego, por. w. 14] są/będą połamane"70.

W w. 18 pojawia się twierdzenie, że Jhwh „zna” dni doskonałych (hebr.

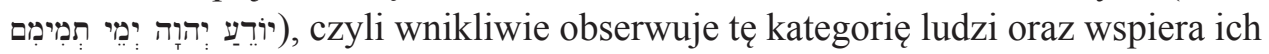
na drodze życiowej ${ }^{71}$, a także zapewnia trwałość ich dziedzictwa ${ }^{72}$. Werset 19 uszczegóławia poprzednią wypowiedź za pomocą zdania „nie będą zawstydzeni

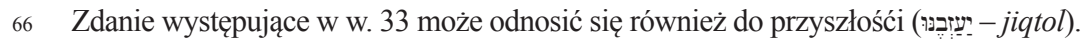

67 Zob. Hossfeld - Zenger, Die Psalmen I, 238; Goldingay, Psalms 1-41, 531.

68 Proponowane w niniejszym artykule podwójne thumaczenie form czasownikowych w. 37 uwzględnia różne możliwości translacji pojawiające się w tłumaczeniach Ps 37 oraz w komentarzach do tego utworu.

69 Tę końcową wypowiedź Ps 37 poprzedza w. 39, w którym zastosowano znaczeniowo bliskie wspomnianym czasownikom rzeczowniki przedstawiające Boga jako wyzwoliciela i bezpieczeństwo

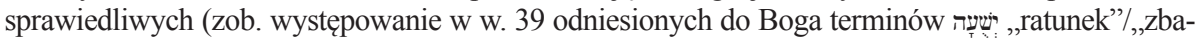

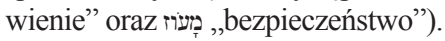

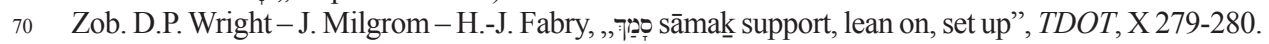

71 Zob. Kraus, Psalmen 1-59, 442; Goldingay, Psalms, 525. Podobną myśl zawiera Ps 1,6: „Jhwh zna

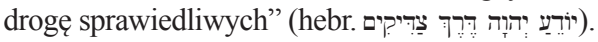

72 Więcej na temat sensu w. 18b czytaj w tej części artykułu, która zajmuje się interpretacją twierdzeń o losie sprawiedliwych. 
w czasie złym, w dniach głodu będą nasyceni”. Pierwsza część tegoż wiersza przekonuje czytelnika, że sprawiedliwi, których dni Jhwh „,zna”, nie doznają zawodu (jako ci, którzy ufają w Bożą pomoc) ${ }^{73}$ wtedy, gdy nastanie w ich życiu trudna sytuacja. Odwrotnie, właśnie w nieszczęściu doświadczą Bożej troski i opieki. Druga część w. 19, która zawiera zdanie paralelne do umieszczonego w w. 19a, przedstawia paradoksalną sytuację, potwierdzającą ujęte wcześniej w sposób ogólny doświadczenie: sprawiedliwi będą nasyceni w dniach głodu, a więc wtedy, kiedy człowiek z reguły doświadcza ostrego niedostatku pożywienia i może znajdować się z tego powodu w niebezpieczeństwie utraty życia.

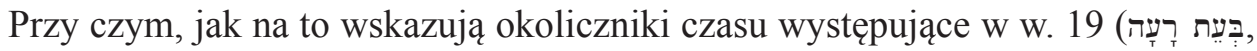
dosłownie „w czasie złym”, בִיפַי רְעָבוֹן dosłownie ,w dniach głodu”), nie chodzi w tym przypadku o Bożą chwilową opiekę, ale o Jego troskę w czasie długotrwałej klęski naznaczonej niedostatkiem ${ }^{74}$.

Także w. 23-24 są pełne przekonania o Bożym wsparciu dla sprawiedliwego. Zastosowany w nich hebrajski termin ą generalnie oznacza silnego męża. W tekstach Psałterza odnosi się jednak do człowieka, którego łączy z Bogiem zażyła relacja, naznaczona od strony ludzkiej ufnością oraz bojaźnią Bożą ${ }^{75}$. W myśl Ps 37 taki człowiek spotyka się ze wsparciem ze strony Jhwh, ponieważ jego zachowanie ${ }^{76}$ zyskuje Boże uznanie: „Jhwh upewnia kroki męża, ponieważ ma upodobanie w jego drodze" "77 (w. 23). Na oznaczenie Jhwh i Jego działalności w stosunku do człowieka, który jest mu bliski i oddany, pojawia się w w. 24 określenie w. 24 mamy do czynienia $\mathrm{z}$ jego sensem dosłownym: Jhwh podtrzymuje rękę padającego człowieka, dzięki czemu ten dosłownie „,nie jest/będzie zrzucony”

73 Zob. Y. Avrahami, בוש in the Psalms - Shame or Disappointment?, JSOT 34/3 (2010) 310 (przyp. 60), a także 308. Z identyczną interpretacją w. 19a mamy do czynienia w thumaczeniu Biblii na język polski z r. 2008. Zob. Pismo Święte Starego i Nowego Testamentu. Najnowszy przekład z języków oryginalnych z komentarzem (Częstochowa: Edycja Świętego Pawła 2008).

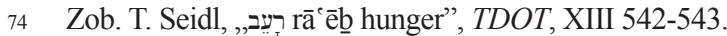

75 Zob. Kosmala, , גָּ gābhar strength, hero", 377, 378-379.

76 W psalmach mądrościowych terminy związane z ,drogą" (w tym rzeczownik דרֶּ ) odnoszą się do zachowania jednostki bądź opisują Boże prowadzenie w życiu konkretnego człowieka. Zob. K. Koch i in., דרוך derekh way, path”, TDOT, III 284. Zdaniem E. Zengera „droga” z w. 23 jest metaforą ludzkiego życia, które jednak ma ukierunkowanie życiowe człowieka sprawiedliwego (zob. Ps 1,6). Zob. Hossfeld - Zenger, Die Psalmen I, 236.

77 Ze względu na identyczność trzech pierwszych słów w hebrajskiej wersji w. 23 i Prz 20,24, a także

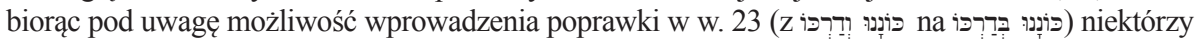
proponują odmienne thumaczenie w. 23 (,kroki męża pochodzą od Boga, trzyma go wyprostowanym na jego drodze, jeśli ma w nim upodobanie"), które byłoby wyrazem przeświadczenia, że to Jhwh ostatecznie decyduje o tym, jaki kierunek będzie miała droga życiowa człowieka (zob. np. Prz

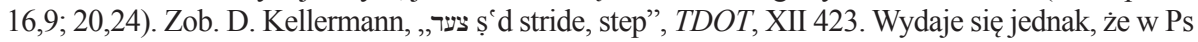
37,23 bardziej chodzi o wyrażenie przeświadczenia o Bożym wsparciu dla człowieka, na co może wskazywać zastosowanie w jego najbliższym kontekście (w. 24) imiesłowu ךị o na określenie Bożej działalności. 


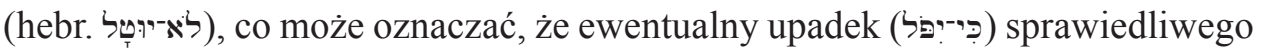
nie doprowadzi do takiego stanu, który uniemożliwiłby mu ponowne powstanie (por. Prz 24,16) ${ }^{78}$. Nakreślony przez psalmistę w w. 24 obraz jest paralelny do obrazu męża, którego kroki są podtrzymywane przez Jhwh z początku w. 23 jeden i drugi przekonują adresata psalmu o wsparciu, jakiego Jhwh udziela tym, którzy tworzą z Nim zażyłą relację.

O tym, że sprawiedliwy jest przedmiotem Bożej nieustannej troski, świadczy

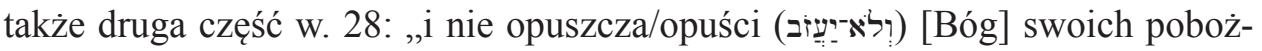
nych/świętych". Zastosowany w tej wypowiedzi rdzeń עזב odnosi się nie tylko do fizycznego odejścia od kogoś, ale może mieć znaczenie prawnego, ekonomicznego, politycznego czy emocjonalnego opuszczenia. W tekstach biblijnych wiąże się on niejednokrotnie z sytuacją wystawienia kogoś na niebezpieczeństwo śmierci ${ }^{79}$. Ze strony Jhwh sprawiedliwy nigdy nie doświadczy owego opuszczenia. Wydaje się, że również w w. 25 mamy do czynienia z podobnym przeświadczeniem o Bożym trwaniu przy sprawiedliwym. W tym miejscu pojawia się bowiem wypowiedź, iż sprawiedliwy nigdy nie był opuszczony: „Byłem młodzieńcem, a jestem starcem, ale nie widziałem sprawiedliwego, który by był opuszczony (נפעיזָב), ani jego potomstwa, które by szukało chleba".

W świetle wypowiedzi przedstawiających niebezpieczną konfrontację człowieka sprawiedliwego i bezbożnego oraz podkreślających nieustanną troskę, której sprawiedliwi doświadczają od Jhwh, czego wyrazem jest definitywne wyzwolenie tej kategorii ludzi z rąk bezbożnych, sprawiedliwi są ukazani adresatowi Ps 37 jako ci, którzy, wbrew poczynaniom bezbożnych, nigdy nie doświadczają upadku.

Nie tylko przyszłe losy sprawiedliwych oraz fakt nieustannej troski, którą nad nimi Bóg roztacza, są przedmiotem zainteresowań psalmisty. Autor natchniony przedstawia sprawiedliwego także od strony tego, co ten posiada, oraz jak się zachowuje w sytuacji dostatku. Przy czym punktem odniesienia w tego typu wypowiedziach jest osoba i zachowanie człowieka bezbożnego.

W w. 16 autor wspomina o bogactwie, dosłownie mnóstwie, nadmiarze bądź dostatku (hebr. החז (המון ) licznych bezbożnych ${ }^{80}$, które są mniej warte niż ,mała cząstka” (hebr. מְעט - dosłownie ,mało), należąca do sprawiedliwego: „lepsze jest to mało, co ma sprawiedliwy, od bogactwa licznych bezbożnych"81. Egzegeci zwracają uwagę na fakt, że dostatek, o którym jest mowa w w. 16, niekoniecznie

Zob. Craigie, Psalms 1-50, 298; Goldingay, Psalms 1-41, 527.

Zob. E.S. Gerstenberger, , עָז 'āzab to abandon”, TDOT, X 586.

Takie rozumienie w. 16 bazuje na masoreckiej wersji tekstu, w której przymiotnik רב , ,liczny” poja-

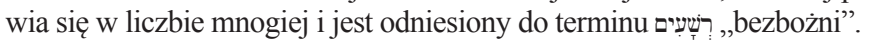

81 Starożytne thumaczenia w. 16, takie jak np. LXX, Peszita bądź tumaczenie Hieronima, biorą pod uwagę liczbę pojedynczą hebrajskiego terminu רֵ, traktując go jako słowo odnoszące się do bogactwa, a nie charakteryzujące bezbożnych. Zob. aparat krytyczny BHS. 
musi oznaczać bogactwa materialnego, np. ilości pieniędzy ${ }^{82}$. W tym miejscu nie chodzi też o krytykę bogactwa oraz podniesienie biedy materialnej do rangi cnoty ${ }^{83}$. Pomocnym przy interpretacji maksymy z w. 16 okazują się podobnego typu porzekadła, które występują w Księdze Przysłów (Prz 15,16 $6^{84 .}$; 16,8 8 ; por. także Tob 12,8$)^{86}$. W ich świetle na pierwszy plan wysuwają się stosunek człowieka do Boga (bojaźń Bożą) bądź jego sprawiedliwość, którym przypisuje się większą wartość niż bogactwu bezbożnych. Wydaje się, że również w analizowanym wierszu chodzi przede wszystkim o zachętę do bycia sprawiedliwym ${ }^{87}$, nawet jeśli to może się wiązać bądź realnie wiąże z posiadaniem mniejszych dóbr ${ }^{88}$. Interpretowana w tym kluczu maksyma z w. 16 staje się jedną z odpowiedzi, których psalmista udziela adresatowi Ps 37, żywiącemu wobec bezbożnych, którym się powodzi, gniew oraz zazdrość (w. 7-8).

Kolejną odpowiedzią na sytuację adresata jest informacja z w. 21, w świetle której bezbożny jest prezentowany jako ten, kto pożycza od innych, ale długu nie oddaje. Jako taki jest przeciwieństwem sprawiedliwego, którego charakteryzują litość i szczodrość: „lituje się i (roz)daje” (zob. także w. 26: „przez cały dzień lituje się i pożycza"). Kontekst najbliższy w. 21 pozwala sądzić, że opisane w nim działanie bezbożnego jest obrazem potępienia, którego ten doświadcza od Boga: „bowiem błogosławieni przez Niego posiądą ziemię, a przeklęci przez Niego będą wycięci" (w. 22) ${ }^{89}$. Losem ludzi należących do kategorii sprawiedliwych jest natomiast wypływająca z posiadania ziemi obfitość, która prowadzi do szczodrości i praktykowania miłosierdzia. Bezbożni, jako ci, których dotyka Boża klątwa, są pozbawieni możliwości korzystania z darów tejże ziemi, dlatego muszą pożyczać na własne utrzymanie. Obraz bezbożnych oraz sprawiedliwych

Zob. Declaisse-Walford - Jacobson - Tanner, The Book of Psalms, 353.

Zob. Craigie, Psalms 1-50, 98.

„Lepiej mało w bojaźni Jhwh, niż wielki skarb i niepokój w nim”.

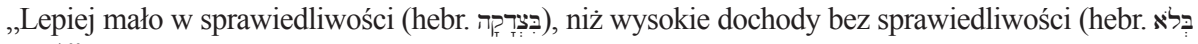

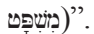

Zob. A. Weiser, The Psalms. A Commentary (The Old Testament Library; Philadelphia: Westminster Press 1962) 319.

Zob. Kraus, Psalmen 1-59, 442.

Zdaniem K. Schaefera aforyzm z w. 16 ma wychować wytrwałość i wnieść pokój do przeżywania sytuacji nacechowanych poniżeniem. Zob. K. Schaefer, Psalms (Berit Olam. Studies in Hebrew Narrative \& Poetry; Collegeville: The Liturgical Press 2001) 92.

Zob. np. Craigie, Psalms 1-50, 298; Goldingay, Psalms 1-41, 527. Inaczej uważa E. Zenger (zob. Hossfeld -Zenger, Die Psalmen I, 236). Zdaniem tego egzegety w w. 21 nie mamy do czynienia z ilustracją błogosławieństwa bądź przekleństwa, które Jhwh zsyła na sprawiedliwego i bezbożnego, ale przedstawia się tam zachowanie bezbożnego i sprawiedliwego. Pierwszy z nich, jako ten, co pożycza i nie oddaje, jest zachłanny i nieuczciwy. W opinii J. Goldingaya w obrazie bezbożnego z w. 21 opisano raczej wielką nędzę tego, kto jest zmuszony do pożyczania, a nie oddając długów wystawia siebie na jeszcze większe niebezpieczeństwo (konsekwencje płynące z niezwrócenia pożyczki). Zob. Goldingay, Psalms 1-41, 527. Przekonanie o tym, że obraz bezbożnego z w. 21 przedstawia jego trudną sytuację materialną wyraża także H.-J. Kraus (Psalmen 1-59, 442). 
z w. 21 pełni dydaktyczną funkcję, podobnie jak informacje o tychże kategoriach osób z w. 16. Ich celem jest pouczyć o tym, jakiej drogi życiowej ma się trzymać adresat psalmu.

Charakteryzując człowieka sprawiedliwego psalmista nie ogranicza się do kontrastowego przedstawienia go na tle bezbożnych. W tekście Ps 37 jest też mowa o sprawiedliwym jako o człowieku mądrym oraz prowadzonym przez

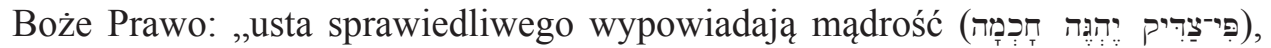
a jego język głosi to, co jest słuszne. Prawo jego Boga jest w jego sercu, jego kroki się nie zachwieją" (w. 30-31). Trzeba zaznaczyć, że Ps 37 jest jedynym tekstem w ramach całego Psałterza, gdzie sprawiedliwy jest charakteryzowany za pomocą hebrajskiej osnowy חכ „być mądrym” (prawie w identyczny sposób jak w przypadku Prz 10,31), co w pełni odpowiada typowemu dla literatury mądrościowej fenomenowi przedstawiania sprawiedliwego w kategoriach mądrości (zob. np. Prz 9,9; 10,31; 11,30; 23,24) ${ }^{90}$. Sprawiedliwy, o którym mowa w tym miejscu, nie jest czytelnikowi Psałterza obcy. Bardzo przypomina człowieka, którego jako wzór postępowania postawił przed nim autor Ps 1: „szczęśliwy człowiek, który ... ma upodobanie w Prawie Jhwh, nad jego Prawem rozmyśla dniem i nocą" (w. 1-2). Dla czytelnika tekstu hebrajskiego podobieństwo między jednym i drugim sprawiedliwym jest jeszcze bardziej widoczne. Mądrość i Prawo są bowiem przedmiotem czynności opisywanej w Ps 1 oraz Ps 37 przy pomocy tego samego hebrajskiego czasownika יחני. Obraz sprawiedliwego z Ps 37 nawet $\mathrm{w}$ pewnym sensie przewyższa obraz sprawiedliwego z Ps 1 , ponieważ w jego świetle Boże Prawo jest nie tylko przedmiotem refleksji czy nawet studiowania (hebr. הגדי (19) ale wewnętrzną zasadą znajdującą się w samym człowieku

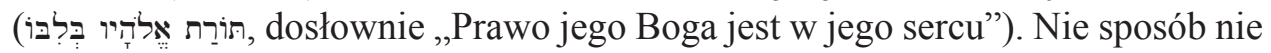
dostrzec $\mathrm{w}$ tym obrazie podobieństwa do nowego przymierza $\mathrm{z}$ proroctwa Jeremiasza, wskutek którego Boże Prawo zostanie wypisane w sercach Izraelitów (Jr 31,31-34). W świetle analizowanego psalmu obecność Prawa Bożego, rozumianego jako Boże pouczenie ${ }^{92}$, we wnętrzu sprawiedliwego decyduje o tym, że zostanie on uchroniony przed popełnieniem błędów moralnych ${ }^{93}$. Charakterystyka sprawiedliwego z w. 30-31, która uwydatnia jego integralny związek z mądrością, bezspornie czyni z niego wzór do naśladowania dla adresata psalmu.

Obraz człowieka sprawiedliwego w Ps 37 byłby niekompletny, gdybyśmy nie zwrócili uwagi na te miejsca utworu, w których jest mowa o sprawiedliwości jako takiej. O niej informuje wprost w. 6, w którym pojawia się rzeczownik צִּק „sprawiedliwość" utworzony od rdzenia צדק , צyć sprawiedliwym”. Hebrajski termin צִדּק należy w tym miejscu rozumieć jako pewien ustanowiony porządek,

\footnotetext{
90 Zob. A. Hurvitz, ,tsdyq = ,wise“ in biblical Hebrew and the wisdom connections of Ps 37”, 110-111.

91 Zob. A. Negoită - H. Ringgren, הדזָד hāghāh roar, mutter, speak”, TDOT, III 322-323.

92 Zob. Kraus, Psalmen 1-59, 443.

93 Zob. Goldingay, Psalms 1-41, 530.
} 
o czym może świadczyć między innymi zastosowanie w w. 6 jako paralelne-

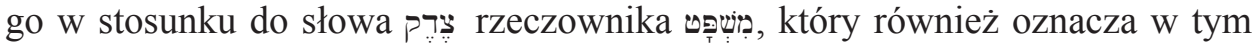
przypadku to, co jest słuszne, porządek dany przez Boga. Rzecz interesująca, że w świetle wspomnianego wiersza jest mowa o sprawiedliwości adresata Ps 37. Autor przedstawia ją jako taką, która dzięki Bożej interwencji wreszcie jakby „zaistnieje”, ujawni się: „wyprowadzi twoją sprawiedliwość jak światło a twoje prawo jak południe". Jest to jedyne miejsce w ramach całego utworu, gdzie adresat psalmu nabiera cech człowieka sprawiedliwego, właściwie już jest widziany jako sprawiedliwy, chociaż jego sprawiedliwość przejawi się w pełni dopiero w przyszłości i to jedynie wtedy, gdy będzie trwał w zażyłej relacji z Bogiem i Jemu w swoim życiu zaufa (w. 4-5). Adresat Ps 37, przeżywający kryzys swoich przekonań społeczno-religijnych (jest świadkiem powodzenia człowieka bezbożnego oraz popełnianego przez niego zła), uzyskuje od Boga potwierdzenie słuszności swojego wyboru życiowego. Jego sprawiedliwość, a więc styl życia mający podstawę $\mathrm{w}$ szeroko rozumianym prawie Bożym, zostanie jako taka potwierdzona przez Boga. Zdaniem Geoffrey'ego Grogana przejawi się to w tym, że sprawiedliwy będzie dysponował ziemią, podczas gdy bezbożnego spotka sąd ${ }^{94}$. O tym, że sprawiedliwość mająca fundament w Bożym porządku jest modelem, według którego warto kształtować swoje życie, świadczy w. 28, który między innymi mówi o akceptowaniu przez Jhwh wszechogarniającej za-

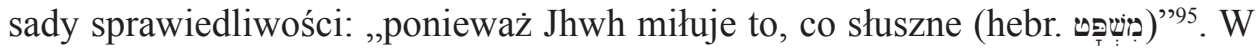
podobnym sensie należy rozumieć wypowiedź z w. 30: „usta sprawiedliwego

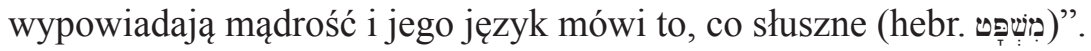

\section{Zakończenie}

Przeprowadzona analiza pozwoliła na odkrycie obrazu człowieka sprawiedliwego i bezbożnego w Ps 37. Są to obrazy radykalnie od siebie różne, a zarazem jakby komplementarne. O sprawiedliwym mówi się najczęściej na tle wypowiedzi o człowieku bezbożnym. W świetle tekstu napięcie między jednym i drugim jest nie do przezwyciężenia, dlatego musi być zażegnane przez samego Boga. I rzeczywiście, niebezpieczeństwo, jakie ludzie bezbożni gotują dla sprawiedliwych, nie powoduje ich definitywnego upadku, bo Jhwh nieustannie się o nich troszczy. Dużą uwagę poświęca się w tekście kwestii przyszłości sprawiedliwego i bezbożnego. Porażce egzystencjalnej bezbożnego przeciwstawia autor natchniony szczęśliwy los sprawiedliwych.

94 Zob. Grogan, Psalms, 91.

95 Zob. G. Wallis - J. Bergman - A. O. Hāhabh love', TDOT, I 110. 
Dlaczego hagiograf przedkłada swoim czytelnikom właśnie takie obrazy sprawiedliwego i bezbożnego? Dlaczego tak dużo miejsca poświęca przy tym przedstawieniu ich przyszłych losów? Dlaczego tak często odwołuje się w tym kontekście do motywu posiadania ziemi?

Trzeba pamiętać, że przedstawienie charakterystyki i losów sprawiedliwego i bezbożnego nie jest pierwszorzędnym celem analizowanego psalmu. Psalmista kieruje swoją naukę do adresata, który pała gniewem w stosunku do ludzi niegodziwych bądź jest tego bardzo bliski. W tym przypadku nie chodzi jednak o zwykłe sprawiedliwe oburzenie. Złość adresata psalmu jest między innymi reakcją na

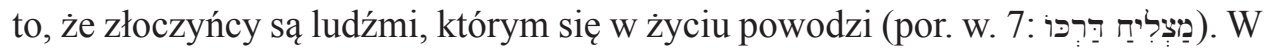
świetle Ps 1, z którym Ps 37 jest połączony poprzez motyw Prawa Bożego, to jednak sprawiedliwy, a nie bezbożny miał stać się człowiekiem sukcesu, pod warunkiem, że oprze na Bożym Prawie całe swoje życie: ,szczęśliwy człowiek ... który ma upodobanie w Prawie Jhwh, nad Jego Prawem rozmyśla w dzień i w nocy. Jest jak drzewo zasadzone nad płynącą wodą, które wydaje owoc w swoim czasie. Jego liście nie więdną, a wszystko, co uczyni, pomyślnie wypada" (Ps 1,1-3; zob. także Jr 17,8). Rzeczywistość, w której żyje adresat Ps 37, jest jednak inna; kwestionuje ona obowiązywalność zasad sformułowanych przez autora Ps 1 . To bezbożny, a nie sprawiedliwy, jest zielonym, pełnym soków drzewem, ponieważ jemu się w życiu powodzi. Warto przypomnieć, że w. 35 analizowanego psalmu charakteryzuje bezbożnego w taki właśnie sposób, a więc jako bujniejące swoją zielenią dzikie drzewo (hebr. אזרְּח wzywa swojego adresata by stronił od gniewu oraz zawiści, a zarazem nawołuje go do ufności Bogu i czynienia dobra ${ }^{97}$. Mędrzec zwraca się do swojego ucznia z zachętą, by ten wkroczył na drogę ,ubogich Jhwh”, by w swoim myśleniu całkowicie złożył swoją nadzieję w Boże ręce. Taka postawa jest poręką szczęśliwego życia, o którym autor mówi w kategoriach posiadania ziemi. Na obietnicę posiadania ziemi przez sprawiedliwych warto spojrzeć przez analogię do twierdzenia o żywotności drzewa z Ps 1. Drzewo przynoszące owoce oraz nigdy nie więdnące jest symbolem powodzenia człowieka, który oparł swoje życie na Bożych zasadach. Obietnica posiadania ziemi przez sprawiedliwych jest zapewnieniem dla wszystkich, którzy wkroczyli na drogę sprawiedliwości, że ich droga ma sens i szczęśliwy koniec. Warto być człowiekiem sprawiedliwym, stronić od

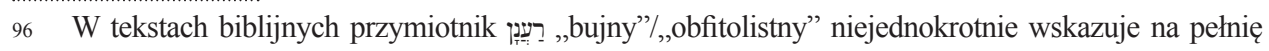
życia, zrealizowaną ludzką egzystencję, zwłaszcza wtedy, gdy w sposób metaforyczny (za pomocą obrazu drzewa) charakteryzuje człowieka sprawiedliwego (zob. np. Ps 52,10; 92,15; Jr 11,16; 17,8).

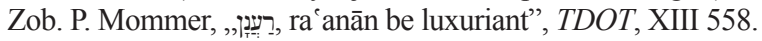

97 Zdaniem S. Łacha gniew i zazdrość, które adresat Psalmu żywi wobec ludzi bezbożnych, są przejawem braku zaufania względem sprawiedliwego Boga. Stąd też w pouczeniu psalmista wzywa do ufności Panu i trwałej wierności względem Niego. Zob. S. Łach, Księga Psalmów. Wstęp-Przekład z oryginalu - Komentarz - Ekskursy (Pismo Święte Starego Testamentu VII/2; Poznań: Pallotinum 1990) 226. 
zła i czynić dobro. Prowadzi to człowieka do trwałego szczęścia. Za mądrego nie może być uznany jednak ten, kto pozwoli, by gniew i zazdrość, jako pozornie „sprawiedliwa” reakcja na zachowanie bezbożnych, zaczęły charakteryzować jego egzystencję, gdyż kryje się w tym niebezpieczeństwo, że dążący do sprawiedliwości sam stanie się człowiekiem niegodziwym (w. 8). Ci, którzy popełniają nieprawość, nie mają jednak przyszłości - szybko znikną z oczu, podobnie jak szybko więdnie trawa. W świetle powyższych uwag informacje o sprawiedliwym i bezbożnym z Ps 37 stają się ważną częścią programu życiowego adresata psalmu. Jest to program, który zawiera liczne zachęty i zapewnienia oraz jest pełen ostrzeżeń. W świetle tego programu sprawiedliwość jako styl życia oparty na Bożym Prawie oraz odznaczający się głęboką osobistą relacją z Bogiem jest wyraźnie lansowaną wartością. Warto być sprawiedliwym, bo „sprawiedliwi posiądą ziemię". Nie należy płonąć gniewem i zazdrością wobec bezbożnego oraz brać „sprawiedliwości” w swoje ręce ${ }^{98}$, przyzwalając na zakorzenienie się zła w sobie samym. Niegodziwego bowiem wbrew pozorom (w. 7) nie czeka nic dobrego, niebawem zniknie, będzie „wycięty”, podobnie jak wycina się drzewo (w. 35-36, zob. także w. 9.22.28.34.38).

\section{Bibliografia}

Alonso Schökel L. - Carniti C., I Salmi (Commenti biblici; Roma: Borla 1992).

Anderson A. A., The Book of Psalms. Volume I. Psalms 1-72 (New Century Bible Commentary; Grand Rapids: Eerdmans 1981).

Avrahami Y., בוש in the Psalms - Shame or Disappointment?, Journal for the Study of the Old Testament 34/3 (2010) 295-313.

Bauks M., „«Das Land erben» oder «die Erde in Besitz nehmen» in Ps 36 (37 MT): ein Übersetzungsvergleich", Die Septuaginta. Texte, Kontexte, Lebenswelten. Kongressakten der Internationalen Tagung Wuppertal, 20.-24.07.2006 (red. M. Karrer - W. Kraus) (Wissenschaftliche Untersuchungen zum Neuen Testament 219; Tübingen: Mohr Sieback 2008) 502-522.

Benun R., „Evil and the Disruption of Order: A Structural Analysis of the Acrostics in the First Book of Psalms", The Journal of Hebrew Scriptures 6 (2006) 1-30, http://www.jhsonline.org/Articles/ article_55.pdf [dostęp: 24.09.2018].

Biblia Hebraica Stuttgartensia (red. K. Elliger - W. Rudolph) (Stuttgart: Deutsche Bibelgeselschaft 1997).

Botterweck G. J., , אביוֹי ebhyôn poor", Theological Dictionary of the Old Testament (red. G.J. Botterweck - H. Ringgren; tł. J.T. Willis - G.W. Bromiley - D.E. Green) (Grand Rapids: Eerdmans 1977) I, 27-41.

Craigie P.C., Psalms 1-50 (Word Biblical Commentary; Waco: Word Books 1983).

Declaisse-Walford N. - Jacobson R.A. - Tanner B.T., The Book of Psalms (The New International Commentary on the Old Testament; Grand Rapids: Eerdmanns 2014).

98 Zob. Vander Hart, "Possessing the Land as Command and Promise", 149. 
Eaton J. H., The Psalms. A Historical and Spiritual Commentary with an Introduction and New Translation (London - New York: Continuum 2005).

Fantuzzo Ch.J., „Acrostic”, Dictionary of the Old Testament Wisdom, Poetry \& Writings. A Compendium of Contemporary Biblical Scholarship (red. T. Longman III - P. Enns) (Nottingham: IVP Academic 2008) 1-4.

Gerstenberger E., עָָָנָ II 'ānâ debase; misery; poor”, Theological Dictionary of the Old Testament (red. G.J. Botterweck - H. Ringgren; tł. J.T. Willis - G.W. Bromiley - D.E. Green) (Grand Rapids: Eerdmans 2001) XI, 230-252.

Gerstenberger E.S., , ָָָ ‘āzab to abandon”, Theological Dictionary of the Old Testament (red. G.J. Botterweck - H. Ringgren; tł. J.T. Willis - G.W. Bromiley - D.E. Green) (Grand Rapids: Eerdmans 1999) X, 584-592.

Goldingay J., Psalms 1-41 (Baker Commentary on the Old Testament Wisdom and Psalms; Grand Rapids: Baker Academic 2006).

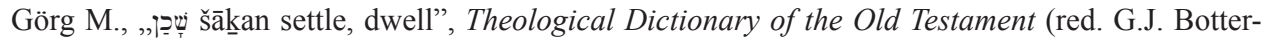
weck - H. Ringgren; tt. J.T. Willis - G.W. Bromiley - D.E. Green) (Grand Rapids: Eerdmans 2004) XIV, 691-702.

Grogan G.W., Psalms (The Two Horizons Old Testament Commentary; Grand Rapids: Eerdmans 2008) .

Hasel G.F., ,כָָרבת kārat cut (off)", Theological Dictionary of the Old Testament (red. G.J. Botterweck - H. Ringgren; tt. J.T. Willis - G.W. Bromiley - D.E. Green) (Grand Rapids: Eerdmans 1995) VII, 339-352.

Hossfeld F.-L. - Zenger E., Die Psalmen I. Psalm 1-50 (Die Neue Echter Bibel. Kommentar zum Alten Testament mit der Einheitsübersetzung; Würzburg: Echter Verlag 1993).

Hurvitz A., ,tsdyq = ,wise“ in biblical Hebrew and the wisdom connections of Ps 37”, "Goldene Äpfel in silbernen Schalen» (red. K.-D. Schunck - M. Augustin) (Beitrage zur Erforschung des Alten Testaments und des antiken Judentums 20; Frankfurt am Main: Peter Lang 1992) 109-112.

Hurvitz A., „Wisdom Vocabulary in the Hebrew Psalter”, Vetus Testamentum 38/1 (1988) 41-51.

Jinkins M., „The Virtues of the Righteous in Psalm 37”, Psalms and Practice. Worship, Virtue, and Authority (red. St. B. Reid) (Collegeville: The Liturgical Press 2001) 164-201.

Johnson B., , „ִ șādaq righteous(ness)", Theological Dictionary of the Old Testament (red. G.J. Botterweck - H. Ringgren; t1. J.T. Willis - G.W. Bromiley - D.E. Green) (Grand Rapids: Eerdmans 2003) XII, 239-264.

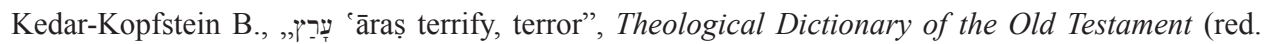
G.J. Botterweck - H. Ringgren; tł. J.T. Willis - G.W. Bromiley - D.E. Green) (Grand Rapids: Eerdmans 2001) XI, 376-378.

Kellermann D., צs ș ș stride, step”, Theological Dictionary of the Old Testament (red. G.J. Botterweck - H. Ringgren; tt. J.T. Willis - G.W. Bromiley - D.E. Green) (Grand Rapids: Eerdmans 2003) XII, 421-424.

Kirkpatrick A.F., The Book of Psalms (The Cambridge Bible for Schools and Colleges; Cambridge: University Press 1951).

Koch K. i in., דרוּך derekh way, path", Theological Dictionary of the Old Testament (red. G.J. Botterweck - H. Ringgren; tt. J.T. Willis - G.W. Bromiley - D.E. Green) (Grand Rapids: Eerdmans 1978) III, 270-293. 
Kosmala H., „גָברִ gābhar strength, hero”, Theological Dictionary of the Old Testament (red. G.J. Botterweck - H. Ringgren; tt. J.T. Willis - G.W. Bromiley - D.E. Green) (Grand Rapids: Eerdmans 1977) II, 367-382.

Kraus H.-J., Psalmen 1-59 (Biblischer Kommentar Altes Testament 15/1; Neukirchen-Vluyn: Neulirchener Verlag 2003).

Łach S., Księga Psalmów. Wstęp - Przekład z oryginału - Komentarz - Ekskursy (Pismo Święte Starego Testamentu VII/2; Poznań: Pallotinum 1990).

Liess K., „«Die auf JHWH hoffen, werden das Land besitzen« (Psalm 37,9). Zur Landthematik in den Psalmen", Heiliges Land (red. M.-Th. Wacker - R. Koerrenz) (Jahrbuch für Biblische Theologie 23; Neukirchen-Vluyn: Neukirchener Verlag, 2009) 47-73.

Lipiński E., , נָָחל nāḥal inherit", Theological Dictionary of the Old Testament (red. G.J. Botterweck - H. Ringgren; tt. J.T. Willis - G.W. Bromiley - D.E. Green) (Grand Rapids: Eerdmans 1998) IX, 319-335.

Lohfink N., „,Die Besänftigung des Messias: Gedanken zu Psalm 37”, ,, Den Armen eine frohe Botschaft": Festschrift für Bischof Franz Kamphaus zum 65. Geburtstag (red. J. Hainz i in.) (Frankfurt am Main: Josef Knecht 1997) 75-87.

Lohfink N., שמדר šmd destroy, remove”, Theological Dictionary of the Old Testament (red. G.J. Botterweck - H. Ringgren; tł. J.T. Willis - G.W. Bromiley - D.E. Green) (Grand Rapids: Eerdmans 2006) XV, 177-198.

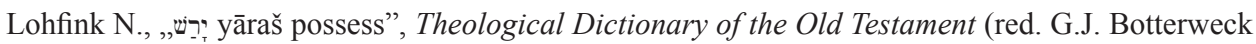
- H. Ringgren; tt. J.T. Willis - G.W. Bromiley - D.E. Green) (Grand Rapids: Eerdmans 1990) VI, 368-396.

Manns F., „Blessed are the Meek for they Shall Inherit the Earth”, Liber annuus 50 (2000) 37-51.

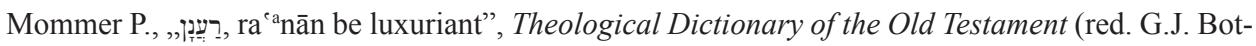
terweck - H. Ringgren; tł. J.T. Willis - G.W. Bromiley - D.E. Green) (Grand Rapids: Eerdmans 2004) XIII, 557-560.

Murphy R.E., The Tree of Life. An Exploration of Biblical Wisdom Literature (Grand Rapids: Eerdmans 2002).

Negoită A. - Ringgren H., הָָָד hāghāh roar, mutter, speak", Theological Dictionary of the Old Testament (red. G.J. Botterweck - H. Ringgren; tł. J.T. Willis - G.W. Bromiley - D.E. Green) (Grand Rapids: Eerdmans 1978) III, 321-324.

Oeming M., Das Buch der Psalmen. Psalm 1-41 (Neuer Stuttgarter Kommentar - Altes Testament 13/1; Stuttgart: Katholisches Bibelwerk 2000).

Ottoson M. - Bergman J., אריץ, 'erets land", Theological Dictionary of the Old Testament (red. G.J. Botterweck - H. Ringgren; tł. J.T. Willis - G.W. Bromiley - D.E. Green) (Grand Rapids: Eerdmans 1977) I, 388-405.

Otzen B., , אבָדָ 'ābhadh perish, destroy”, Theological Dictionary of the Old Testament (red. G.J. Botterweck - H. Ringgren; tł. J.T. Willis - G.W. Bromiley - D.E. Green) (Grand Rapids: Eerdmans 1977) I, 19-23.

Pikor W., Rola ziemi w przymierzu Boga z Izraelem (Wydawnictwo KUL: Lublin 2013).

Pismo Święte Starego i Nowego Testamentu. Najnowszy przekład z języków oryginalnych z komentarzem (Częstochowa: Edycja Świętego Pawła 2008). 
Ringgren H. - Seebass H., , עִ pāša ment (red. G.J. Botterweck - H. Ringgren; tł. J.T. Willis - G.W. Bromiley - D.E. Green) (Grand Rapids: Eerdmans 2003) XII, 133-151.

Saur M., „Frevler und Gerechte. Überlegungen zum theologischen Ort von Psalm 37”, Nächstenliebe und Gottesfurcht. Beiträge aus alttestamentlicher, semitistischer und altorientalischer Wissenschaft für Hans-Peter Mathys zum 65. Geburtstag (red. H. Jenni - M. Saur) (Alter Orient und Altes Testament 439; Münster: Ugarit Verlag 2016) 375-392.

Seebass H., אחָרִית 'achâith after(wards); end; last”, Theological Dictionary of the Old Testament (red. G.J. Botterweck - H. Ringgren; tt. J.T. Willis - G.W. Bromiley - D.E. Green) (Grand Rapids: Eerdmans 1977) I, 207-212.

Seidl T., ,רָעִ rāeēb hunger”, Theological Dictionary of the Old Testament (red. G.J. Botterweck H. Ringgren; tł. J.T. Willis - G.W. Bromiley - D.E. Green) (Grand Rapids: Eerdmans 2004) XIII, 533-543.

Schaefer K., Psalms (Berit Olam. Studies in Hebrew Narrative \& Poetry; Collegeville: The Liturgical Press 2001).

Schreiner J., , שָׁ ‘āwel injustice”, Theological Dictionary of the Old Testament (red. G.J. Botterweck - H. Ringgren; t1. J.T. Willis - G.W. Bromiley - D.E. Green) (Grand Rapids: Eerdmans 1999) $\mathrm{X}, 522-530$.

Steingrimsson S., , זמם zmm plan”, Theological Dictionary of the Old Testament (red. G.J. Botterweck - H. Ringgren; tt. J.T. Willis - G.W. Bromiley - D.E. Green) (Grand Rapids: Eerdmans 1980) IV, 87-90.

Stendebach F. J., ,שָָ šālôm peace”, Theological Dictionary of the Old Testament (red. G.J. Botterweck - H. Ringgren; tł. J.T. Willis - G.W. Bromiley - D.E. Green) (Grand Rapids: Eerdmans 2006) XV, 13-49.

Theological Dictionary of the Old Testament (red. G.J. Botterweck - H. Ringgren; tt. J.T. Willis G.W. Bromiley - D.E. Green) (Grand Rapids: Eerdmans 1977-2006) I-XV.

Vander Hart M. D., „Possessing the Land as Command and Promise”, Mid-Amerika Journal of Theology 4/2 (1988) 139-155.

Wallis G. - Bergman J. - Haldar A. O., , אָזָ 'āhabh love”, Theological Dictionary of the Old Testament (red. G.J. Botterweck - H. Ringgren; tt. J.T. Willis - G.W. Bromiley - D.E. Green) (Grand Rapids: Eerdmans 1977) I, 99-118.

Weiser A., The Psalms. A Commentary (The Old Testament Library; Philadelphia: Westminster Press 1962).

Witte M., „Psalm 37 im Spannungsfeld von Weisheit und Eschatologie”, M. Witte, Von Ewigkeit zu Ewigkeit. Weisheit und Geschichte in den Psalmen (Biblisch-Theologische Studien 146; Neukirchen-Vluyn: Neukirchener Verlag 2014) 39-65.

Wright D.P. - Milgrom J. - Fabry H.-J., , סָָ sāmak support, lean on, set up", Theological Dictionary of the Old Testament (red. G.J. Botterweck - H. Ringgren; t1. J.T. Willis - G.W. Bromiley - D.E. Green) (Grand Rapids: Eerdmans 1999) X, 276-286. 